NBER WORKING PAPER SERIES

NEW HOPE FOR THE EXPECTATIONS
HYPOTHESIS OF THE. TERM
STRUCTURE OF INTEREST RATES

Kenneth A. Froot

Working Paper No. 2363

NATIONAL BUREAU OF ECONOMIC RESEARCH

1050 Massachusetts Avenue

Cambridge, MA 02138

August 1987

The research reported here is part of the NBER's research program in Financial Markets and Monetary Economics. Any opinions expressed are those of the author and not those of the National Bureau of Economic Research. 


\title{
New Hope for the Expectations Hypothes is \\ of the Term Structure of Interest Rates
}

\begin{abstract}
Survey data on interest rate expectations are used to separate the forward interest rate. into an expected future rate and a term premium. Thesc components are used to test separately two competing alternative hypotheses in t.ests of the term structure: that the expectations hypothesis does not hold, and that expected future long rates over- or underreact to changes in short rates. While the spread consistently fails to predict future interest rate changes, we find that the nature of this failure is different for short versus long maturities. For short maturities, expected future rates are rational forecasts. The poor predictions of the spread can therefore be attributed to variation in term premia. For longer-term bonds, however, we are unable to reject the expectations theory, in that a steeper yield curve reflects a one-for-one increase in expected future long rates. Here the perverse predictions of the spread reflect investors' failure to raise sufficiently their expectations of future long rates when the short rate rises. We confirm earlier findings that bond rates underreact to short rate changes, but now this result cannot be attributed to the term premium.
\end{abstract}

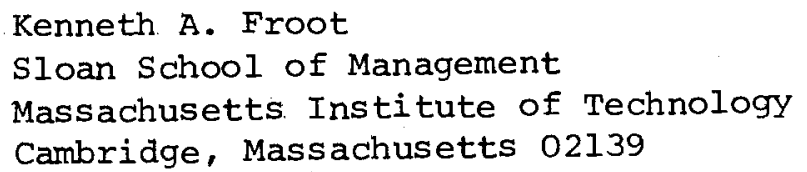




\title{
New Hope for the Expectations Hypothesis \\ of the Term Structure of Interest Rates
}

\author{
Kenneth A. Froot. \\ Sloan School of Management, \\ Massachusetts Institute of Technology \\ Cambridge, Massachusett.s 02139
}

If the attractiveness of an economic hypothesis is measured by the number of papers which statistically reject it, the expectations theory of the term structure is a knockout. Only a small fraction of the many tests beginning with Macaulay (1938) have found strong evidence in support of the expectations hypothesis, and even fewer can reject statistically the alternative hypothesis that the spread between long- and short-term interest rates has no predictive power at all for future interest rate changes. ${ }^{1}$ Confoundingly, the most common finding in U.S. postwar data has been that when short-term rates rise relative to long-term rates, future long-term rates tend to rise even further. That is, the expectations hypothesis does worse than even the näive model that subsequent interest rate changes are always zero. ${ }^{2,3}$

Naturally, the null hypothesis in these tests is a joint hypothesis: that all of the variability in the spread between long- and short-term interest rates is attributable to expected future interest

\footnotetext{
${ }^{1}$ It is not quite a misnomer to speak of the expectations hypothesis. To be sure, Cox, Ingersoll and Ross (1981) show that different interpretations of the expectations bypothesis are mutually inconsistent, and that one variant (the yield-tomaturity expectations hypothesis) is inconsistent with equilibrium in discretr time. Shiller, Camplocll and Schoenholtz (1983) and Campbell (1986), however, derive linearizations of the expectations hypothesis wich resolve respectively the problems of mutual inconsistency and of consistency with equilibrium. When referring to the term structure, I have in mind the discrete-time linearization of Shiller, Campbell and Schoenholtz (1983). See section 3 below for further details.

2 In their recent study of the term structure, Campbell, Shiller and Schoenlıoltz, re inark that tlin resiliency of the expectations hypothesis reminds them of Jerry in the Tom and Jerry cartoons. I tend to think of Alan Blindrr's "Joe Palooka effect" (applied originally to the rapid U.S. recovery from the 1982 recession). Each time inflatahle Jor is knocked to the ground, he bounces energetic ally back, unharmed and grinning.

8 Among the many studies which reject the expectations theory in U.S. postwar data are Shiller (1979), Fama (1984a, b), Mankiw (1986), Mankiw and Summers (1984), Mankiw and Miron (1980, 1987), Modigliani and Shiller (1973), Friedman (1979), Jones and Roley (1983), Shiller, Campbell and Schoenholtz (1983) and Camphell and Shiller (1984, 1987). Fama (1984a), tests the expectations hypothesis at the extreme short end of the spectrum (using one-month bills) and finds that the spread has some positive predictive power for future interest rate changes. Mankiw and Miron (1980) also discover evidence of the spread's predictive power, but only as recently as 1890 -1915. Nevertheless, both of these papers statistically reject restrictions imposed hy the expectations hypothesis. Campbell and Shiller (1987) and Fama and Bliss (1987) find that medium-and long-term spreads have positive predictive power for short rate changes further into the future. While this could be an implication of the expectations theory, it is also an implication of many other models in which slort rates and term premia follow a jointly stationary stochastic process. Shiller (1981), presents the strongest evidence in support of the expectations hypothesis. He finds not only that the spread has statistically significant predictive power for excess returns on five year bonds, but also that his data cannot reject the expectations theory. Shiller (1987) provides a complete survey of the literature.
} 
rate changes, and that expectations are rational. Without additional information, it is obviously not possible to conclude either the extent to which each of these maintained hypotheses fails, or the extent to which each is qualitatively responsible for the perverse predictions of the yield curve. One consequence of this ambiguity is that authors tend to attribute the sources of predictable excess returns on long rates in accordance with their own priors. Some argie that time-varying term premia are responsible for the rejection, while others suggest that over- or under-reaction of long rates (relative to what is rational) may be driving the results.

More recently, Mankiw and Miron (1986), Mankiw and Summers (1984) and Startz (1982) have suggested that the poor performance of the expectations throry can be interpreted not only as evidence of a time-varying term premium, but also as evidence that the premium is more variable than are expected future changes in short-term interest rates. Such an interpretation implies that observed changes in the spread are attributable primarily to variation in risk. This view follows directly under rational expectations from two simple facts: first, that the spread does change over time (when the short rate rises, the spread tends to fall), and second, that short-term interest rates are close to a random walk on levels. That this "random-walk" view emerges from such simple descriptive statistics is powerful evidence that recent findings of bias in the long rate's predictions of future short rates are robust to the precise period and statistical methodology used to test the expectations theory. Indeed, the view that the variation in forward premia predominantly reflects risk has already been articulated in the context of a variety of asset markets. For example, variation is regularly observed in forward and future discounts in foreign exchange and nonagricultural commodity markets, but this variation does not help explain subsequent spot price changes.

Nevertheless, the notion that large and highly variable term premia are responsible for the failure of the expectations hypothesis, particularly at the very short end of the maturity spectrum, is unappealing to many observers. Thus Shiller (1981), Campbell. Shiller and Schoenholtz, (1983), Campbell and Shiller (1984) and Mankiw and Summers (1984) have suggested that the apparent

\footnotetext{
'Hodrick and Srivastava (1984, 1986a, b), present evidence that forward and future exchange rates are biased predictors of future spot. exchange rates and interpret this to mean that the variance of the forrign exchange risk premium is greater than the variance of expected depreciation. For an alternative interpretation see Froot and Frankel (1986). They employ survey data in a manner analogous to the current paper in order to determine the importance of risk premia and expectational errors in explaining bias in the forward exchange rate. Fama and French (1980) present. eridence that variation in several commodity future discounts primarily reflects variation in risk.
} 
failures of the expectations hypothesis might be explained instead by myopic expectations, which provoke an overreaction in bond prices to changes in short-term intcrest rates. Their tests, however, support the opposite conclusion that long-term rates underreact to short rate changes. Indeed, if one eschews explanations based on a time-varying term premium, the underreaction hypothesis follows directly from the two empirical facts above. Under the expectations theory, long rates should move one-for-one with short rates which follow a random walk. Because they have a smaller variance than short rates, long rates must underreact.

Put baldly, we have no way of choosing between these alternatives; we do not know how variable the term premium is, nor have we a sense for how reliable the expectations imbedded in long rates are. In this paper we extract information from surveys of intcrest rate expectations in an effort to resolve these basic issues. These relatively new data sources allow us to determine both qualitatively and statistically the extent to which expectational errors and the term premium are each responsible for the biased predictions of the spread. Indecd, our results indicate a striking difference in the importance of these two explanations both at opposite ends of the maturity spectrum and across the term structures of different countries.

The paper is structured as follows. Section 1 briefly describes the data and their coverage, and discusses the interpretation we give to the survey responses. In Section 2 we briefly review the linearized model of the term structure. The standard test of whether the spread is an unbiased predictor of future interest rate changes is performed in section 3. This is the most common method of testing the expectations hypothesis. The reported deviation from the null hypothesis is separated in section 4 into a component attributable to a failure of the expectations theory and a component attributable to systematic expectational errors. Section 5 then uses the surveys to determine the extent to which the first part of the joint hypothesis - that the survey expectations themselves conform to the expectations theory - fails in the standard test. In other words, we use the survey data to test directly the expectations hypothesis. Section 6 tests for the significance of the second component in the failure of the joint hypothesis: systematic expectational errors. Here we use the surveys to explore the hypotheses that forecasted interest rate changes are excessively volatile and that future interest rates tend to over- or underreact to contemporancous short rate changes. In section 7, we present some simple but revealing statistics from the surveys to clarify the role of the 
term premium in the pricing of bills and bonds. Section 8 concludes.

\section{The Data}

Three sources of survey data on future interest rate expectations are used in this paper. The first survey is conducted by the Goldsmith-Nagan Money Market Letter, which has recently merged with the investor newsletter, Reporting on Governments, and adopted its name. ${ }^{5}$ At the end of each quarter from mid-1969 to the end of 1986, Goldsmith-Nagan (GN) has surveyed financial market participants on their expectations of interest rates on 3 month Treasury Bills, 3 month Eurodollar deposits, 12 month Treasury Bills, the return on the Buyer bond index, ${ }^{6}$ and the 30 year mortgage rate. $^{7}$ Each respondent is asked to give his or her expectation of the level of each of these rates in 3 and 6 months time. The duration and consistency of this sct of surveys -- currently, 70 contiguous quarters of data for a variety of instruments - is highly unusual.

The second survey source is Money Market Services, Inc (MMS), which conducts weekly and biweekly surveys of interest rates. While the coverage of these data is far more limited than the Goldsmith-Nagan surveys, they are helpful in providing breath. In London, every two weeks from the beginning of 1983 until October 1984, MMS cauvassed 30 traders on the Euromarket desk of various banks for their expectations on the level of 3 month Eurodollar, EuroDM, Europound and Euroyen deposits in 3 months time. In Sydney Australia from unid-1985 to early 1987, MMS asked bank traders on a weekly basis their expectations of 10 year bonds in one month's time.

While most economists distrust survey data, probably few would argue with the statement that, used correctly, surveys can potentially add to our understanding of the behavior of expectations. Surveys of interest rate expectations are especially appealing, since they permit direct measurement of both the expected future short-term interest rate and the associated term premium. Nevertheless, skeptics rightfully argue that it is hard to accept that a collection of relatively careless verbal responses, even from informed market participants, can be identified directly with the market expectation. $^{9}$

\footnotetext{
${ }^{8}$ Friedman $(1979,1980)$ were the first papers to use data from these survers.

${ }^{6}$ This is an index of 20 general obligation issues with 20 year maturities, The index is designed to reflect current yield-tomaturity on new issue quotes.

${ }^{7}$ Morigage instruments carry "put" options, which distort their duration and risk characteristics. Existing mortgages which were granted at rates higher than those prevailing are often refinanced, deming rreditors the capital gains they would otherwise earn if prepayment. was not allowed.

${ }^{8}$ Actual daily interest rates were obtained from DRI when available, and othrrwise from the Wall Street Journal and the London Financial Times.

${ }^{\circ}$ One could also question the existence of a unique market expertation when agents have disparate beliefs. See Rubinstein
} 
The tests performed in this paper do not assume that the median survey response is equivalent to the market expectation. Instead, we think of the surveys as being subject to the same kinds of problems inherent in any single proxy for "the" market expectation. Whatever the proxy, call it. $x_{1}$, it can be represented by the equation:

$$
x_{l}=\left(\mathbf{i}_{i+j}^{(k-j)}\right)^{e}-\mathbf{i}_{i}^{(j)}+\epsilon_{\ell, j}
$$

where $\left(i_{l+j}^{(k-j)}\right)^{e}$ represents the markets' (unobservable) expectation at time $t$ of the interest rate on a $k-j$ period bill issued in period $t+j, \mathbf{i}_{l}^{(j)}$ is the current "short-term" interest rate on $\mathrm{j}$ period bills, and $\epsilon_{\ell, j}$ is a residual term.

There are several choices for $x_{t}$, each of which implies a corresponding residual. One possibility is to define the forward interest rate less the short rate as $x_{\ell}$, which implies the error term, $\epsilon_{\ell, j}$, is identified with the forward term premium. Of course, if the point is to test for the presence of a term premium, this formulation is merely a definition of the alternative hypothesis.

The second and most common choice for $x_{l}$ is the change in the actual realized interest rate at time $t+j, \mathbf{i}_{t+j}^{(k-j)}-\mathbf{i}_{i}^{(j)}$. Then the residual term is the ex post expectational crror, usually attributed to "news". The disadvantage to conscripting $\mathbf{i}_{f+j}^{(k-j)}$ to be a proxy for the market expectation is that we wish to test separately the hypothesis that the expectational errors are in fact conditionally independent of $\left(\mathbf{i}_{i+j}^{(k-j)}\right)^{\mathbf{e}}$. Learning on the part of the market. in response to nonstationarities or process switching, irrational behavior, and "peso problems" in which a low probability event does not occur a representative number of times in the sample, would all lead to small sample failures of conditional independence.

The third candidate for $x_{t}$ is the median survey expectation, which we denote by $s_{t+j}^{(k-j)}$. In this case, $\epsilon_{t, j}$ is identified with measurement error in the survey data. This error arises from factors such as imperfect synchronization of participants responses, high volatility of interest rates, and the use of a median response elicited from a small fraction of the population of market participants. Just as in the foregoing case of $e x$ post prediction errors, the measurement crror here must be conditionally independent of the market expectation to permit us to draw reliable inferences. However, now the properties of the error term will be immune to the efferts of learning, irrationality, or peso probleins.

(1974) for conditions under which agents expectations can be successfully aggregated inton the expertations of a well-defined representative agent. 


\section{The Model}

Throughout the paper, we adopt the linearized model of the term structure of Shiller, Campbell and Schoenholtz (1983). While this model employs only approximations to actual forward rates and holding period returns, it has several properties that are useful for our purposes. First, as noted in the introduction, such a linearization resolves any ambiguities which arise when choosing among alternative definitions of the expectations hypothesis. Second, there are a bewildering variety of ways to test the implications of the expectations hypothesis. With the linearized model, however, we can test a single specification and draw implications for the many other specifications found in the literature. This is important since one of our objectives is to use the surveys to help explain prior findings. Third, the linearization appears to sacrifice relatively little acruacy in comparison with nonlinear models. ${ }^{10}$

Under this model, the current long rate is a weighted average of expected future short rates:

$$
\mathbf{i}_{l}^{(k)}=D_{k}^{-1} \sum_{l=0}^{k / j-1} \gamma^{j l}\left(\mathbf{i}_{l+j l}^{(j)}\right)^{e}
$$

where $\gamma=(1+i)^{-1}$ is the discount factor, and $D_{k}$ is Macaulay`s (1938) definition of duration for this $k$ period bond when priced at par:

$$
D_{k}=\frac{1-(1+\bar{i})^{-k}}{1-(1+\bar{i})^{-1}}
$$

where $i$ is the coupon rate. Pure discount bonds, such as the Treasury bills we analyze have a zero coupon, so that their duration is just the time to maturity. ${ }^{11}$

Given the model in equation (2), a linearized approximation to the forward interest rate at time $t$ on a $k-j$ period bill, $j$ periods into the future is:

$$
\mathbf{f}_{i}^{(j, k-j)}=\frac{D_{k} \mathbf{i}_{i}^{(k)}-D_{j} \mathbf{i}_{l}^{(j)}}{D_{k}-D_{j}}
$$

The term premium on a $k$ period bond from period $t$ to period $t+j$ is then defined as the difference between the forward rate and the expected future spot rate:

$$
\mathbf{f}_{i}^{(j, k-j)}-\left(\mathbf{i}_{i+j}^{(k-j)}\right)^{\mathbf{e}}=\theta_{i}^{(j, k-j)}
$$

\footnotetext{
${ }^{10}$ Shiller, Campbell and Schoenholtz (1983) present. evidence that the linearized forward rates are close to the true forward rates, particularly over the relatively short forecast horizons considered in the present paper. Campliell (1980) demonstrates the accuracy of the linearization in continuous time.

${ }^{11}$ For the longer-term bonds investigated below, we approximate the coupon rate on each instrument ly assuming it is equal to that instrument's average return over the sample period.
} 
Thus the expectations hypothesis implies that. $\theta_{i}^{(j, k-j)}=0$. i.e.. that forward rates are equal to expected future spot rates. The expected holding-pcriod yield is the expected yield obtained fron purchasing a $k$ period bond, holding it for $j$ periods, and then selling it:

$$
\left(\mathbf{h}_{i}^{(k, j)}\right)^{e}=\frac{D_{k} \mathbf{i}_{i}^{(k)}-\left(D_{k}-D_{j}\right)\left(\mathbf{i}_{t+j}^{(k-j)}\right)^{\mathbf{e}}}{D_{j}}
$$

From equations (2), (4) and (6) the excess holding-period return on a $k$ peliod bond held for $j$ periods is proportional to the risk premium defined in equation (5):

$$
\left(\frac{D_{j}}{D_{k}-D_{j}}\right)\left(\left(\mathbf{h}_{\imath}^{(k, j)}\right)^{\mathbf{e}}-\mathbf{i}_{\imath}^{(j)}\right)=\theta_{i}^{(j, k-j)}=\mathbf{f}_{i}^{(j, k-j)}-\left(\mathbf{i}_{i+j}^{(k-j)}\right)^{\mathbf{e}}
$$

In this linearized model of the term structure, the expectations hypothesis implies both that expected excess returns on long-term bonds are zero and that forward rates are equal to expected future spot rates.

\section{A Standard Test of the Expectations Hypothesis}

There are a myriad of testable implications which follow from the model in section 2. Our first task is to choose a method of testing the term stmucture which best facilitates comparison with a variety of earlier work. Consider one standard regression test of the expectations hypothesis, in which the subsequent change in the short rate is regressed on the forward premium: ${ }^{12}$

$$
\mathbf{i}_{t+j}^{(k-j)}-\mathbf{i}_{i}^{(j)}=\alpha+\beta\left(\mathbf{f}_{i}^{(j, k-j)}-\mathbf{i}_{i}^{(j)}\right)+\mu_{t+j}
$$

The restrictions imposed jointly by the expectations hypothesis and rational expectations are that $\alpha=0, \beta=1$, and the residual term reflects purely random "news." Because the null hypothesis imposes conditional independence of the residual, OLS can be used to estimate equation (8).

Of course, many studies do not test equation (8) itself. Often either the change in the longterm rate or the realized excess holding return is used as the depcndent variable, and the spread or the forward premium above the long-term rate is used as the regressor. Given the model in equations (2), (4) and (6), these tests are exactly equivalent. To demonstrate this, Table 1 presents a complete set of univariate regression tests of the expectations hypothesis. The table is set up as a

\footnotetext{
12 Fama and Bliss (1987) study the forecast power of the spread for spot rate changes further into the future.
} 
Chinese Menu of term structure regressions: a researcher chooses one from column A and regresses it on one from column B. ${ }^{13}$

From the linearized model in equation (4), the elements in column B are algebraically identical. Under the linearized model of the term structure, all of the elements in column A can be obtained from Al by adding or subtracting multiples of the elements in column B. Thus all possible permutations yield regressions which are statistically identical. We use the particular formulation in equation (8) - a regression of $\mathrm{A} 1$ on $\mathrm{B} 2$ - because the null hypothesis of $\alpha=0, \beta=1$ does not depend on the particular maturity, $k-j$, or forecast horizon, $j$, chosen. This turns out to be convenient since the surveys cover a diverse set of maturities. Suppose, for example, one were to regress $\mathrm{A} 2$ on either $\mathrm{B} 1$ or $\mathrm{B} 3$. These are the more familiar formulations in the literature for tests of the expectations hypothesis at longer maturities. Using Table 1, the estimated coefficients in these regressions would be $\frac{\hat{\beta} D_{k}}{D_{k}-D_{j}}-1$ and $1+(\hat{\beta}-1) D_{k} / D_{j}$, respectively, where $\hat{\beta}$ is the OLS estimate of equation (8).

Most tests of equation (8), or equivalently, tests using an element from column $A$ and an element from column B in Table 1, find that $\beta$ is less than one in U.S. data. Frequently, for shorter maturities the coefficient $\beta$ is not statistically different from zero, so that the forward premium is of no help in forecasting future changes in the short rate. Indeed, it is not unusual to find a coefficient less than zero, which implies that an optimal predictor actually places negative weight on the forward rate.

One alternative hypothesis to explain these findings is the existence of a time-varying term premium. Under this alternative, the probability limit of the coefficient $\beta$ can be written:

$$
\beta=\frac{\operatorname{cov}\left(\left(\mathbf{i}_{++j}^{(k-j)}\right)^{e}-\mathbf{i}_{i}^{(j)}, \theta_{i}^{(j, k-j)}\right)+\operatorname{var}\left(\left(\mathbf{i}_{i+j}^{(k-j)}\right)^{e}-\mathbf{i}_{i}^{(j)}\right)}{\operatorname{var}\left(\mathbf{f}_{i}^{(j, k-j)}-\mathbf{i}_{i}^{(j)}\right)}
$$

Clearly, if all of the variability in the spread reflects variation in expected interest rate changes, $\left(i_{i+j}^{(k-j)}\right)^{\mathbf{e}}-\mathbf{i}_{i}^{(j)}, \beta$ will be equal to one. At the opposite extreme, the finding that $\beta=0$ would imply that all of the variation in the yield curve can be attributed to variation in term premia. To see

\footnotetext{
${ }^{17}$ In terms of Table 1: Mankiw and Summers (1984) regress $A 2$ on B1; Shiller, Campleell and Schoenlioltz (1983) regress $A 1$ on $B 2$ and $A 2$ on B3; Mankiw and Miron $(1986,1987)$ regress A1 on B1; Fama (1984) regresses A1 on B2 and A4 on B2; Campbell and Shiller (1984) regress $A 4$ on $B 1$; Shiller regresses $A 2$ on $B 3$, and sn on.
} 
this, note that $\beta$ can be equivalently written:

$$
\beta=1-\frac{\operatorname{cov}\left(\left(\mathbf{i}_{++j}^{(k-j)}\right)^{\mathbf{e}}-\mathbf{i}_{i}^{(j)}, \theta_{l}^{(j, k-j)}\right)+\operatorname{var}\left(\theta_{i}^{(j . k-j)}\right)}{\operatorname{var}\left(\mathbf{f}_{l}^{(j, k-j)}-\mathbf{i}_{f}^{(j)}\right)}
$$

Several authors, including Startz (1982) and Mankiw and Miron (1986), appear to endorse this extreme hypothesis that all of the fluctuations in the yicld curve are unrelated to changes in interest rate expectations, and reflect instead variation in term premia. Other authors find such an alternative somewhat unattractive because it is hard to understand where all the variation in risk would come from, especially at the very short end of the maturity spectrum. One could take the view mentioned in Mankiw and Miron (1986) that, if interest rate expectations are static (by which we mean $\left.\left(i_{i+j}^{(k-j)}\right)^{e}-i_{i}^{(j)}=0\right)$, even a small amount of variation in the term premium would lead to strong rejections of the theory. But this explanation gets the expectations hypothesis off the hook only if one is willing to accept that changes in the slope of the yield curve have little economic significance.

A second alternative hypothesis holds that systematic expectational errors in the sample period are responsible for the well-established deviations from the null hypothesis. Shiller (1981), Shiller, Campbell and Schoenholtz (1983), and Mankiw and Summers (1984) investigate explicitly this alternative. All three papers consider the possibility that irrational expectations are manifest in the overreaction of long-term bond prices to changes in short rates. If we interpret the market's expectation of future short rates to be the mathematical expectation in equation (2), one version of the overreaction hypothesis implies that the parameter $\gamma$ is too large, so that the market places too much weight on current short rates relative to what is rational. As mentioned earlier, these papers find no evidence in favor of the overreaction hypothesis; indeed, because $\beta$ is always less than one, the data consistently support the opposite conclusion that long-tern bond prices move too lit.tle. Many observers find this second alternative as unappealing as the first because it involves a failure of markets to be fully rational. But even those who express sympathy with the view that expectational errors are systematic find implausible the hypothesis that bond prices do not vary enough.

\subsection{The Results}

Tables $2 \mathrm{a}$ and $2 \mathrm{~b}$ present estimates of equation (8) using the $e x$ post interest rates, $\mathbf{i}_{1+j}^{(k-j)}$, realized $j$ periods after the surveys were conducted. These are our standard tests of the term 
structure. Table 2a summarizes estimates for the sample corresponding to the Goldsmith-Nagan survey dates, while Table $2 b$ does the same for the MMS survey dates. In terms of our notation, the time to maturity of each financial instrument in Tables $2 a$ and 21 is given by $j-k$, and the forecast horizon is given by $j$. For each forecast horizon, instruments are listed in order of increasing duration. Note that for the Goldsmith-Nagan data, both 3 and 6 montl forecast horizons are estimated for most of the assets. Before discussing the parameter estimates we pause briefly to clarify several econometric issues.

Regressions in all of the tables that follow are estimated using OLS, with standard errors calculated using Hansen's (1982) Generalized Method of Moments (GMM). Each of the surveys was conducted regularly at a time interval smaller than the longest forecast horizon. The resulting overlap in forecasts implies that even under the null hypothesis, the residuals will follow a moving average process. Our estimated standard errors and F-statistics account for this type of serial correlation. Using a technique due to Newey and West (1985), we also correct for the possibility that the estimated covariance matrixes will not be positive definite. This estimator discounts the lth order autocovariance by $1-l /(m+1)$. As the sample size tends to infinity, $m$ can be any fixed integer. But for any given finite sample, it is an open question as to how small $m$ must be in order to guarantee a positive definite covariance matrix. In most of the upcoming regressions we used $m=2 P$, where $P$ is the order of the MA process of the residuals. This yields slightly larger standard errors than those obtained by setting $m=P$, which Newey and Wrst (1985) show to guarantee positive definiteness in any finite sample.

In addition, the null hypothesis does not imply that the residuals will be homoskedastic. For each of the regressions reported in the following tables, White (1980) t.est.s for conditional heteroskedasticity were performed. As one might expect, some of the regressions contained residuals for which the hypothesis of conditional homoskedasticity could be rejected, and others did not. When the results on heteroskedasticity are mixed in this way, threc reporting strategies are available. The first would be to report for all of the regressions the standard errors that are consistent only under homoskedasticity. This strategy scems undesirable since several data scts showed evidence of severe conditional heteroskedasticity. A second strategy would be to report. only heteroskedasticity-consistent standard errors. The rase for this approach would appear to 
be the strongest because the resulting standard errors will be asymptotically consistent regardless of whether conditional heteroskedasticity is present. Evidence in Froot (1987a), however, shows that this GMM estimator is severely downward biased in small samples. We therefore pursue a third strategy of reporting both sets of standard errors (along with both sets of t-statistics and F-statistics), and conduct inference based on the larger of the two. This scems to be the most cautious approach given the small sample problems with these covariance matrix estimators. ${ }^{14}$

All of the regressions below were estimated with constant terms, which we do not report to save space. For the Goldsmith-Nagan surveys dates, which run from the third quarter of 1969 to the last quarter of 1986 , a slope-parameter dummy, $\beta_{c c}$, is included in all the regressions during 1980 when the Fed was changing operating procedures and Jimmy Carter's temporary Special Credit Restraint Program was announced, put in place, and then dismantled. In addition, we tried splitting the sample into pre- and post-1979 subsamples (based on the change in Fed operating procedures), but we could not reject the hypothesis that the coefficients were equal in the two subsamples.

Turning to the results, Tables $2 \mathrm{a}$ and $2 \mathrm{~b}$ tell a familiar story. All of the point estimates of $\beta$ in Table $2 \mathrm{a}$ are less than one, and all but one are significantly less. For the shorter-term 3 month and 12 month bills the parameter estimates are statistically indistimguishable from zero, so that we are unable to reject the hypothesis that the spread is of no use in forecasting future changes in short rates. At the 6 month forecast horizon, the point estimates for these shorter-term instruments are actually negative.

In the case of the two longer-term instruments in Table 2a, the Buyer Bond index and the rate on $\mathbf{3 0}$ year mortgages, the coefficient estimates are significantly different from both zero and one. At these longer maturities, it is not surprising to find that the spread has predictive power for differences between tomorrow's long rate and today's short rate. Nevertheless, this predictive power should not be interpreted as providing support for the expectations hypothesis. Consider the usual tests of the expectations hypothesis at longer maturities, which asks the spread to predict the upcoming change in the long rate:

$$
\mathbf{i}_{i+j}^{(k-j)}-\mathbf{i}_{i}^{(k)}=\alpha_{1}+\beta_{1}\left(\mathbf{i}_{i}^{(k)}-\mathbf{i}_{i}^{(j)}\right)+\mu_{1, l, j}
$$

\footnotetext{
14 Of course, the heteroskedasticity-corrected standard errors should be smaller than those computed assuming homosked astic. ity if the second moment of the residual is negatively correlated with the second moment of the regressors. It seems implausible that in the regresions below the variance of the residuals is systematically low when the spread is large. Our reporting strategy therefore reflects a prior belief that smaller heteroskedasticity-consistent standard errors are more likely to be the result of finite-sample bias than an indicator of the true behavior of the residuals and regressors.
} 
where from Table 1 the null hypothesis is that $\beta_{1}=D_{j} /\left(D_{k}-D_{j}\right)$, a number slightly greater than zero. Even though $\beta$ may be significantly greater than zero, $\beta_{1}$ can still have the wrong sign. For the case of the Buyer Bond index at the six month forecast horizon, $\hat{\beta}_{1}=\frac{\hat{\beta} D_{k}}{D_{k}-D_{j}}-1=(0.6355$ $\times 1.0500)-1=-0.3322$ with a standard error of $\frac{0.0748 D_{k}}{D_{k}-\bar{D}_{j}}=0.0748 \times 1.0426=0.0786$. The finding that $\beta_{1}$ is significantly less than zero shows that the slope of the yield curve systematically predicts in the wrong direction the future change in the long rate. This finding is almost universal in tests of long maturities on U.S. post-war data. The point here is that estimates of $\beta$ which are statistically less than one, yet also statistically greater than zero, still provide a strong qualitative rejection of the expectations hypothesis.

Interestingly, the credit controls dummy term, $\beta_{\mathrm{cc}}$, shows that the spread does have additional positive predictive power when a preannounced, temporary (and large) change in monetary policy takes place. This is reminiscent of the finding in Mankiw and Miron (1986) that the spread had predictive power for future short rate changes around the turn of the century when there were large seasonal fluctuations in short rates.

Table $2 \mathrm{~b}$ contains estimates of equation (8) for interest rates of a variety of countries. For the shorter-term 3 month Eurocd's of the dollar, DM, pound and yen, there is only mixed evidence against the null hypothesis. ${ }^{15}$ Strikingly, the hypothesis that the spread is an unbiased forecaster of future short rate changes is most strongly rejected in the U.S. data. In all the other cases, the hypothesis that the spread is of no positive value in forecasting future short rate changes, i.e. that $\beta \leq 0$, can be rejected. Indeed, in the case of 3 month Europound deposits and Australian 10 year government bonds, the point estimates of $\beta$ are greater than one. On the other hand, the U.S. the point estimate is large and negative. Could it be that the expectations hypothesis fares considerably worse in the U.S. than in other countries?

Overall the results show little support for hypothesis that the forward rate is an unbiased predictor of future interest rate changes - the usual finding in test.s of the U.S. term structure. One could interpret the evidence as favorable to either of the alternative hypotheses mentioned above. Bias in the predictions of the spread could be due to a term premium which is positively correlated with the spread, or to a failure to adjust expectations of fut.ure rates rapidly enough.

\footnotetext{
${ }^{15}$ During the period when the MMS surveys on the Eurocd's were conducted, therr were no important capital controls in effect for these currencies. As a consequence, the Euromarket term structure reflected closely the trerm structure within each of the country's borders.
} 


\section{Decomposition of the Standard Test}

We can now use the surveys to split the deviation from the null hypothesis in Tables 2 a and $2 \mathrm{~b}$ into a term attributable to systematic expectational errors and a term attributable to the risk premium. In the spirit of equation (1), we define the survey expectation as equal to the unobservable true market expectation plus measurement error:

$$
\mathbf{s}_{f+j}^{(k-j)}=\left(\mathbf{i}_{1+j}^{(k-j)}\right)^{\mathbf{e}}+\epsilon_{\uparrow, j}
$$

Similarly, the ex post realized spot rate is equal to the market's expectation plus a prediction error:

$$
\mathbf{i}_{f+j}^{(k-j)}=\left(\mathbf{i}_{t+j}^{(k-j)}\right)^{\mathbf{e}}+\eta_{t, j}
$$

Using equation (13) to split the actual change in the interest rate into an expected change and a prediction error, the coefficient $\beta$ in equation (8) converges in probability to:

$$
\beta=\frac{\operatorname{cov}\left(\left(\mathbf{i}_{l+j}^{(k-j)}\right)^{e}-\mathbf{i}_{i}^{(j)}, \mathbf{f}_{i}^{(j, k-j)}-\mathbf{i}_{f}^{(j)}\right)+\operatorname{cov}\left(\eta_{t, j}, \mathbf{f}_{f}^{(j, k-j)}-\mathbf{i}_{f}^{(j)}\right)}{\operatorname{var}\left(\mathbf{f}_{f}^{(j, k-j)}-\mathbf{i}_{f}^{(j)}\right)} .
$$

Now $\beta$ can be rewritten as one (the null hypothesis) plus a deviation attributable solely to the term premium and a deviation attributable solely to systematic expectational errors:

$$
\beta=1-\beta_{\mathrm{tp}}+\beta_{\text {ee }}
$$

where

$$
\begin{aligned}
& \beta_{\mathrm{tp}}=\frac{\operatorname{cov}\left(\left(\mathbf{i}_{t+j}^{(k-j)}\right)^{e}-\mathbf{i}_{f}^{(j)}, \theta_{f}^{(j, k-j)}\right)+\operatorname{var}\left(\theta_{f}^{(j, k-j)}\right)}{\operatorname{var}\left(\mathbf{f}_{f}^{(j, k-j)}-\mathbf{i}_{f}^{(j)}\right)} \\
& \beta_{\mathrm{ee}}=\frac{\operatorname{cov}\left(\eta_{t, j}, \theta_{l}^{(j, k-j)}\right)+\operatorname{cov}\left(\eta_{t, j},\left(\mathbf{i}_{f+j}^{(k-j)}\right)^{e}-\mathbf{i}_{f}^{(j)}\right)}{\operatorname{var}\left(\mathbf{f}_{f}^{(j, k-j)}-\mathbf{i}_{f}^{(j)}\right)}
\end{aligned}
$$

Although the true market expectation and true term preminm are unobscrvable both $\beta_{\text {tp }}$ and $\beta_{\text {ee }}$ can be measured using the survey data, providing that the survey measurement error term, $\epsilon_{t, j}$, is purely random. Clearly, $\beta_{\mathrm{tp}}$ is zero if the variance of the term preminu is zero - that is, if expectations conform to the expectations hypothesis - and $\beta_{e c}$ is zero if expectations are rational.

Table 3 presents point estimates of the components of $\beta$ to gain a sense for their economic significance; we test for the each component's statistical significance in the following sections. There are several striking facts which leap out from this table. First, all of the estimates for $\beta_{e e}$ in the U.S. 
data are negative, even though different survey sources are uscd. By contrast, the estimates for the other countries are all positive. Note that an estimate of $\beta_{p e}<0$ contributes to the usual finding of $\beta<1$, while $\beta_{\mathrm{ee}}>0$ actually raises the parameter $\beta$ above one. Thus more than 100 percent of the deviation from the expectations hypothesis in countries other than the U.S. is attributable to variation in term premia. In the U.S., a positive portion of the deviation is attributable to expectational errors.

The second striking fact to emerge from Table 3 is the different behavior of short versus long durations. While we rejected the unbiasedness of the spread at all maturities, that the estimates of $\beta_{\mathrm{tp}}$ are much larger for the shorter-term instruments than for the longer-term instruments. In the case of the Buyer Bond index at both the 3 and 6 month horizons, the contribution of the term premium is to increase the estimate of $\beta$ above one. Moreover, the qualitative contribution of $\beta_{\mathrm{tp}}$ to the overall deviation from the null hypothesis is relatively large in comparison with the contribution of $\beta_{\mathrm{ee}}$ at the shorter end of the maturity spectrum, and relatively small at the longer end of the spectrum. Table 3 thus indicates that the qualitative importance of the term premium in rejections of the expectations hypothesis is disproportionately large for shorter-term asset.s. While risk may play an important role in the pricing of long-term bonds (sce section 7 below), its economic importance in failures of the spread to predict forthcoming long-rate changes is small.

\section{A Direct Test of the Expectations Hypothesis}

We now attempt to investigate directly the first altemative hypothesis advanced in the foregoing section: that the null hypothesis in equation (8) is rejected because of a time-varying term premium. In terms of the decomposition of $\beta$, we wish to test whether the first component is statistically different from zero. This is most easily accomplished by regressing the survey expected change on the forward premium:

$$
\mathbf{s}_{1+j}^{(k-j)}-\mathbf{i}_{i}^{(j)}=\alpha_{2}+\beta_{2}\left(\mathbf{f}_{i}^{(j, k-j)}-\mathbf{i}_{i}^{(j)}\right)+\mu_{2 . l, j}
$$

Notice that equation (18) is a direct test of the expectations hypothesis, so that the null hypothesis is $\alpha_{2}=0$ and $\beta_{2}=1$. The size of the F-statistic testing these restrictions is a general measure of the importance of the term premium. The error term in equation (18), $\mu_{2,1, j}$, can be interpreted as random measurement error in the survey data. As a consequence, our estimatc of $\beta_{2}$ is immune to 
measurement error and reflects instead the behavior of the unobservable market expectation.

Equation (18) allows us to test a second hypothesis. From equation (16), we have that the probability limit of the coefficient $\beta_{2}$ is:

$$
\beta_{2}=1-\beta_{\mathrm{t}, \mathrm{p}}
$$

The finding that $\beta_{2}$ is statistically indistinguishable from one is thus equivalent to the hypothesis that the second column in Table 3 is insignificantly different from zero. Put differently, a finding of $\beta_{2}=1$ implies we cannot reject the hypothesis that the variance of the term premium is zero (or, more precisely, that the covariance of the term premium with the forward premium is zero). Notice also that a test of $\beta_{2}=1$ may shed light on the presence of measurement errors in the returns on long-term bonds. Mankiw (1986) and Shiller (1979) consider the possibility that such measurement error is responsible for the poor predictions of the spread. A finding of $\beta_{2}=1$ would suggest that this type of measurement error is unimportant.

There are two particular alternative hypotheses in equation (18) which interest us. The first. would be the hypothesis that expected interest rate changes arc static, or at least unrelated to the level of the spread. Here the appropriate hypothesis test is $\beta_{2}=0$. A second, and related hypothesis, allows for a time-varying term premium and asks whether the variance of expected interest rate changes is equal to the variance of the term premium. For short-term instruments it is useful to write the coefficient as:

$$
\beta_{2}=\frac{\operatorname{var}\left(\left(\mathbf{i}_{i+j}^{(k-j)}\right)^{e}-\mathbf{i}_{\ell}^{(j)}\right)-\operatorname{var}\left(\theta_{f}^{(j, k-j)}\right)}{2 \operatorname{var}\left(\mathbf{f}_{\ell}^{(j, k-j)}-\mathbf{i}_{f}^{(j)}\right)}+1 / 2
$$

If $\beta_{2}$ is less than one-half, the variance of the term premium is greater than the variance of the expected interest rate changes. For longer-term instruments, movements of $\left(i_{t+j}^{(k-j)}\right)^{\mathbf{e}}-\mathbf{i}_{i}^{(j)}$ reveal less about changes in expectations than movements of $\left(i_{t+j}^{(k-j)}\right)^{e}-i_{f}^{(k)}$. For these maturities it is more appropriate to compare the variance of long rate clianges with the variance of the term preminm. Some manipulation of equation (20) yields that:

$$
\beta_{2}=\frac{D_{j}}{2 D_{k}}\left(\frac{\operatorname{var}\left(\left(\mathbf{i}_{i+j}^{(k-j)}\right)^{\mathbf{e}}-\mathbf{i}_{l}^{(k)}\right)-\operatorname{var}\left(\theta_{i}^{(j, k-j)}\right)}{2 \operatorname{var}\left(\mathbf{f}_{t}^{(j, k-j)}-\mathbf{i}_{i}^{(k)}\right)}-1\right)+1
$$

Thus if $\beta_{2}>1-\frac{D_{j}}{2 D_{k}}$, the variance of expected long rate changes is greater than the variance of the term premium. 


\subsection{Results}

Tables $4 \mathrm{a}$ and $4 \mathrm{~b}$ contain the estimates of equation (18). To begin, note that the DurbinWatson statistic in most of the regressions rejects the hypothesis that the residuals are serially uncorrelated. Naturally, the regression parameters are still consistent in the presence of serial correlation. In order to construct standard errors for Tables $4 \mathrm{a}$ and $4 \mathrm{~b}$, we use the covariance matrix estimator suggested by Newey and West (1985) to handle serial correlation and heteroskedasticity of unknown form. Their covariance matrix estimator guarantees that the estimated covariance matrix is positive definite by discounting the off-diagonal terms in Hansen's (1982) GMM covariance matrix by $1-l /(m+1)$, where $m$ is now $T^{.25}$. The use of both homoskedastic and heteroskedasticityconsistent standard errors is continued here as above.

Notice that for all of the instruments with a duration of one year or less, the coefficient $\beta_{2}$ is significantly less than one. Thus not only are the corresponding estimates of $\beta_{t p}$ given in Table 3 qualitatively important deviations from unbiasedness, they are statistically significant as well. This is strong evidence against the expectations hypothesis at the short end of the maturity spectrum. The F-tests in the last column of each table show the overall importance of the term premium in the survey data; in every case the size of the statistic is sufficient to permit rejection at the one percent level.

A second feature of the estimates for shorter duration instruments in Table $4 \mathrm{a}$ is that without exception the estimates of $\beta_{2}$ are greater than the estimates of $\beta$ from Table $2 a$ for the U.S. data. In other words, expectations conform more closely to the expectations hypothesis than the usual $e x$ post regressions in Table 2 a reveal. This is not the case for the data from countries other than the U.S. reported in Table $4 \mathrm{~b}$. Several studies have indeed found that the spread is a better predictor of future interest rate changes in countries other than the U.S. ${ }^{16}$ Tables $4 \mathrm{a}$ and $4 \mathrm{~b}$ suggest that these findings do not reflect any meaningful differences in the way expectations are formed. Table 4b indicates that the expectations theory is equally valid in thr U.S., U.K., West Germany and Japan for short maturities. The deviations from unbiasedness observed in Tables $2 a$ and $2 b$ - which at first might appear to suggest that the expectations hypothesis fares worse in the U.S. than in other countries - must then be due to expectational errors.

\footnotetext{
${ }^{16}$ See, for example, Mankiw (1986).
} 
A third feature of the estimates of $\beta_{2}$ for the short-term bills is that we can reject the hypothesis that expectations are static. In all of the regressions, $\beta_{2}$ is consistently positive and statistically greater than zero.

Fourth, note that while expectations are not static, they vary considerably less than term premia for the short-term instruments: the point estimates of $\beta_{2}$ for 3 and 12 month bills are consistently small enough to conclude that the variance of the term premium is greater than the variance of the expected change. Nevertheless, in only one of the regressions using 3 month bills can we reject the hypothesis that the variance of the term premium is equal to the variance of the expected change in short rates (i.e., $\beta_{2}=1 / 2$ ).

While the shorter maturities do not provide much evideuce to support the expectations hypothesis, the longer maturities tell a different story. The F-tests for $\alpha_{2}=0 . \beta_{2}=1$ reject for 30 year mort.gages, but not for Buyer Bonds. ${ }^{17}$ Nevertheless, all of the estimates of $\beta_{2}$ for the Buyer Bond index and 30 year mortgage rate are statistically indistinguishable from one at the one percent level. Indeed, the point estimates for the Buyer Bond index are actually greater than one. We therefore cannot reject the hypothesis that long-maturity estimates of $\beta_{\mathrm{tp}}$ in Table 3 are zero.

Finally, in the longer-term U.S. instruments we cannot reject either the hypothesis that the variance of the term premium is equal to the variance of expected long rate changes or the hypothesis that the variance of the term premium is zero. ${ }^{18}$

\section{Tests of Rational Expectations}

We now turn to the second alternative hypothesis that has becn advanced to explain rejections of the null hypothesis in equation (8): expectational errors. While therc are many possible tests for a systematic component to these errors, we choose only those specifications which provide insight. into the particular alternative hypotheses we wish to explore. More specifically, the survey data give us a unique opportunity to test the over- and underreaction hypothesis dircctly. Shiller, Campbell and Schoenholtz (1983), Cainpbell and Shiller (1984) and Mankiw and Summers (1984) tested for overreaction, but to do so they were forced to impose the expectations theory as a maintained

\footnotetext{
${ }^{17}$ The difference in the $F$-statistics for these two instruments is due primarily to differences in the constant term, $\alpha_{2}$, which in turn is due to tax-free status of the long-term bonds in the Buyer Bond index and the prepayment. option on 30 year mortgages. Because of these special features, one would not want to attribute differences in risk premia exclusively to duration.

${ }^{18}$ In the case of the Buyer Bond index 6 month forecasts, we do reject the hypothesis that $\operatorname{var}\left(\left(i_{1+j}^{(k-j)}\right)^{c}-i_{i}^{(k)}\right)=$ $\operatorname{var}\left(\theta_{i}^{(j, k-j)}\right)$. In this case, $1-D_{j} / 2 D_{k}=0.952$ which is 2.25 standard deviations from 1.0310 . thre rstimatir of $\beta_{2}$.
} 
hypothesis.

\subsection{Excessive or Insufficient Forecast Volatility?}

Suppose the market's expectation of the future interest rate is a linear combination of the contemporaneous short rate and an arbitrary combination of other inputs: ${ }^{19}$

$$
\left(\mathbf{i}_{1+j}^{(k-j)}\right)^{e}=\omega_{1} \mathbf{i}_{1}^{(j)}+\left(1-\omega_{1}\right) \mathbf{x}_{1}
$$

Similarly, the actual realized interest rate is assumed to be a linear combination of the same factors, plus a stochastic news term:

$$
\mathbf{i}_{i+j}^{(k-j)}=\omega_{2} \mathbf{i}_{1}^{(j)}+\left(1-\omega_{2}\right) \mathbf{x}_{1}+\mu_{3, t, j}
$$

Subtracting equation (22) from (23), and substituting for $\mathbf{x}_{1}$ we have:

$$
\mathbf{i}_{i+j}^{(k-j)}-\left(\mathbf{i}_{i+j}^{(k-j)}\right)^{e}=\alpha_{3}+\beta_{3}\left(\left(\mathbf{i}_{1+j}^{(k-j)}\right)^{e}-\mathbf{i}_{f}^{(j)}\right)+\mu_{3, l, j}
$$

where $\beta_{3}=\frac{\omega_{1}-\omega_{3}}{1-\omega_{1}}$. Under the null hypothesis that the market expectation is rational, $\alpha_{3}=\beta_{3}=0$, and the residual, $\mu_{3, l, j}$, is purely random.

The alternative hypothesis in equation (24) is that there is excessive or insufficient forecast volatility, or equivalently, that expected future rates over- or underreact to short rate changes. Suppose that $\beta_{3}$ is greater than zero, expectations place a greater weight on the contemporaneous short rate than is rational. In such a case, a lower value of $\omega_{1}$ would tend to reduce the mean squared expectational error, or equivalently, would tend to raise the variance of expected interest rate changes. To see this note that equation (20) can be rewritten:

$$
\left(\mathbf{i}_{i+j}^{(k-j)}\right)^{e}-\mathbf{i}_{i}^{(j)}=\left(1-\omega_{1}\right)\left(\mathbf{x}_{i}-\mathbf{i}_{i}^{(j)}\right)
$$

Thus if $\beta_{3}$ is negative, expected interest rate changes are cxcessivcly volatile. Here agents could improve their forecasts by reducing fractionally their expectations of future interest rate changes. In this case, agents' expectations of future rates do not move enough in response to the current short rate: expected rates underreact to spot rate changes. ${ }^{20}$

\footnotetext{
19 The vector $a_{t}$ may also include contemporaneous interest rates.

${ }^{30}$ Froot (1987b) investigates the implications of tests of excess forecast. volatility for the alternative hypothesis of Shiller (1981), that asset prices are "too" volatile.
} 
Tables $5 \mathrm{a}$ and $5 \mathrm{~b}$ present estimates of equation (24), substituting for the market expectation, $\left(i_{t+j}^{(k-j)}\right)^{e}$, the survey measure, $s_{i+j}^{(k-j)}$. In Table 5a, the point estimates of $\beta_{3}$ are all less than zero, an indication that expected interest rate changes are too volatile relative to what is rational. The estimates for the 3 month instruments, however, are not statistically significant. There is no evidence that agents could improve their forecasts of future short rates. At the other end of the maturity spectrum, Table 5 a provides evidence that expectatious of future long rate changes are indeed excessively volatile. This conclusion, however, does not carry over to the estimates for Australian long-term bonds in Table $5 \mathrm{~b}$. Here $\beta_{3}$ is significantly positive, indicating that investors could improve their forecasts by increasing multiplicatively their expectations of future changes in the long-term bond rate.

There is one signific ant problem, however, with the regressions presented in Tables $\mathbf{5 a}$ and $\mathbf{5 b}$. According to equation (12), the survey data represent noisy estimates of the narket's expectation. In contrast with all our prior regressions, which used $s_{l+j}^{(k-j)}$ only on the left-hand side, our estimates of equation (24) employ the surveys on both sides. Accordingly, measurement error in the survey data will bias $\hat{\beta}_{3}$ toward minus one, so that findings of $\beta_{3}<0$ should be viewed with some skepticism. Nevertheless, there is no evidence of excessive forecast volatility for the 3 month instruments of Table $5 \mathrm{a}$, even in the presence of measurement error.

\subsection{Reaction to the Long Rate}

The solution to the classic errors-in-variables problem is of course to find instruments for the regressors which are correlated with it, but uncorrelated with the measurement error. Based on the results presented in Tables $4 \mathrm{a}$ and $4 \mathrm{~b}$, we have an obvious candidate: the forward interest rate. We can therefore run a regression of the survey prediction error on the spread as an instrumental variables test for the presence of excess forecast volatility:

$$
\mathbf{i}_{i+j}^{(k-j)}-\left(\mathbf{i}_{1+j}^{(k-j)}\right)^{e}=\alpha_{4}+\beta_{4}\left(\mathbf{f}^{(j, k-j)}-\mathbf{i}_{f}^{(j)}\right)+\mu_{4,1, j}
$$

where the null hypothesis is again that $\alpha_{4}=\beta_{4}=0 .{ }^{21}$

This specification is useful in several ways. First, it allows a test of excessive forecast volatility that is free of the trouble from measurement error. Second, it allows us to test whether the deviation

\footnotetext{
21 We use OLS to estimate equation (26) instead of IV because the test of $\beta_{4}=0$ is imariant to the estimation method in this case.
} 
from unbiasedness attributable to expectational errors is significant. By inspection, the coefficient $\beta_{4}$ is the second component of the deviation from the null hypothesis in Table 3:

$$
\beta_{4}=\beta_{\text {ee }}
$$

We can give a third interpretation to $\beta_{4}$ in equation (26). In section 6.1 , we found evidence that the expected future rate reacts insufficiently to changes in short rates, making expected interest rate changes too volatile. We can think of equation (26) as asking whether expected future rates respond sufficiently to changes in the long rate. Under this interpretation, a finding that $\beta_{4}<0$ implies that expected future rates react excessively to increases in the spread. To see this, note that by replacing $x_{t}$ with $f_{f}^{(j, k-j)}$ in equations (23) and (24) and then taking the difference we have equation (26), with $\beta_{4}=\omega_{1}-\omega_{2}$. A finding that $\beta_{4}<0$ implies that $\omega_{1}$ is "too" small: as before, expectations place insufficient weight on the contemporaneous short ratc, but in addition now place excessive weight. on the contemporaneous long rate. The oppositc holds if $\beta_{4}>0$.

Estimates of equation (26) are given in Tables $6 a$ and $6 b$. The results agree closely those in Tables $5 \mathrm{a}$ and $5 \mathrm{~b}$. There is substantial evidence at the longer maturities that the estimates of $\beta_{\text {ee }}$ from Table 3 are highly significant. In addition, these estimates of $\beta_{4}$ confirm the tentative conclusion from Table $5 a$ that expected future rate changes in the longer maturities are excessively volatile. Expectations appear excessively sensitive to changes in long rates for instruments with longer duration. Agents would do better to place more weight on the contemporaneous short rate and less weight on the contemporaneous long rate in forming their expectations. This finding is in agreement with that in Mankiw and Summers (1984) and Campbell and Shiller (1984), but here the results cannot be interpreted as evidence of a term premium.

For the shorter maturities, however, expectational errors do not appear to be at all systematic. This finding also agrees with the results in Table 5a, which show little evidence of excessive or insufficient forecast volatility at the short end of the maturity spertmum.

Table $6 \mathrm{~b}$ presents estimates of equation (26) for different countries. Among Germany, the U.K., Japan and Australia, the U.S. appears unique in the tendency for expectations to overreact to changes in the spread. In these other countries, the positive point estimates of $\beta_{4}$ indicate that if anything expected future rates underreact to changes in the spread. These findings (together with those in Tables $5 a, 5 b$ and $6 a$ ) could be consistent with a belief among investors that short 
term U.S. rates are asymptotically more regressive than post-war sample experience shows, while short rates in other countries have turned out to be more regressive than expected.

\section{Variation in the Term Premium}

Our findings thusfar could be summarized as documenting the importance of term premia for instruments of shorter duration and the unimportance of term premia for instruments of longer duration in the biased forecasts of the spread. Could it be that risk is important in pricing short-term bills yet unimportant in the pricing of long-term bonds? In this section we ignore the restrictions implied by expectations hypothesis and investigate the behavior of the t.erm premium directly. To preview our findings, the answer to the above question is no. Risk premia become increasingly important in pricing bonds as their duration increases.

Table 7 presents means of the data used in the foregoing tests, expressed in percent per annum. In the first column is the spread (here the forward rate less the current short rate). Using the survey data, we separate the spread into an expected change and a term premia, $\theta_{i}^{(j, k-j)}$. Provided that. any measurement error in the surveys is random, these means will be consistent estimates of the true market values. In column (4) is the holding premium, $h_{i}^{(k, j)}-i_{i}^{(j)}$, or the expected excess return from holding a $k$ period bond for $j$ periods. Note that the holding premium generally increases with duration: the average expected excess return to holding 6 month bills for 3 months is 0.50 percent per annum, while the average expected excess return to holding tax exempt 20 year Buyer bonds for 3 months is 3.05 percent per annum.

Taken by itself, the observation that premia rise with duration is not evidence of the importance of risk in the pricing of long-term instruments. We would also like to sec the relative variability of the premia. We do this in two ways. First, it is interesting to sce directly the actual survey premia even though they are contaminated by measurement error. Figures 1 and 2 display the term structure of the premia for a 3 month holding period for several instruments in the Goldsmith-Nagan dataset. It is clear that as duration increases, both the mean and the variability of the survey holding premium increase dramatically. If the measurement error is roughly the same magnitude for 6 the month bills as it is for 20 year Buyer Bonds and 30 year mortgages, then the premia for these long-term bonds is relatively precisely measured. Even though the size of the premium for 6 month bills is relatively small, a premium of 100 basis points (which is not unısual) on U.S. government Tbills 
still seems large in absolute terms. The surveys suggest that term premia rose substantially during periods of high interest rate volatility. ${ }^{22}$

While these figures are of interest, it is possible that the variability of the measurement error increases with duration and that the errors are contemporaneously correlated across instruments. To remove the measurement error we obtained the predicted values from a regression of the survey expectation on a constant, the current, short rate, and the current long rate, and then subtracted the forward rate to obtain the term premium. As a benchmark measure, we estimated predictable ex post returns on these instruments from a regression of the actual realized interest rate on the same regressors. Two of these premia measures -6 month holding premia for 9 month Tbills and Buyer Bonds - are graphed in Figures 3 and 4, respectively. Summary measures for each asset are reported in Table 8 .

Two striking observations come out of Figures 3 and 4 . First and foremost is the powerful visual impression created by how closely the survey premium (after being purged of any measurement error) moves with predictable excess returns for the short maturities in Figure 3. Contrast this with the markedly different behavior of the two series for longer maturities graphed in Figure 4. Figure 3 implies that the short-maturity surveys do not tell us any thing new about term premia that we could not have learned with ex post realizations (though we did need the surveys to find this out), while the long-maturity surveys differ radically from the predictable excess returns on bonds.

The second striking fact in Figures 3 and 4 is that the survey premia become substantially less volatile than predictable excess returns as duration increases. Neverthcless, variation in the survey premium becomes increasingly pronounced at longer maturities. even after measurement error is removed. In Figure 4 the survey premium is much smoother than predictable excess returns, which exhibit enormous swings. Changing perceptions of risk are clearly an important determinant of changes in bond prices. Nevertheless, at first glance the survey premia appear less inportant in pricing long-term assets than predictable excess returns.

Table 8 evaluates the statistical significance of fluctuations in these two measures of risk premia. For each asset we report the point estimate for the variance and the probability that the variance is

\footnotetext{
${ }^{22}$ Naturally, it is impossible to present graphs of all the survey series. Little information is lost. ly our selective presentation, however, since the characteristics we mention are shared for all the datia.
} 
equal to zero (in parentheses). The probabilities are from F-tests that the coefficients on the long and short rates in the regressions are jointly zero. Though the estimated variance of predictable excess returns is often huge, we frequently cannot reject the hypothesis that the actual variance is zero. By contrast, we strongly reject the hypothesis that the survey premia are constant. Thus, while risk appears more variable when extracted from excess returns, it is measured less precisely than when extracted from the surveys.

Finally, note that the survey premia in Figures 3 and 4 appear reasonable: they are highly positively correlated with nominal interest and inflation rates. By contrast, the behavior of predictable excess returns in Figure 4 is less easily understood. 


\section{Conclusions}

We have used survey data on interest rate expectations to investigate the reasons why the spread is such a poor predictor of future interest rate changes. Our major findings are summarized:

(1) We confirm earlier findings that predictions of future interest rate changes by the spread contain bias of a similar nature for short and long maturities. The explanations for this bias, however, differ markedly at opposite ends of the maturity spectrum.

(2) The surveys on short-term U.S. government securities indicate the existence of a term premium which is both large and variable. The failure of the spread to predict in an unbiased way future short-term interest rate changes is predominantly attributable to the time variation in this premium. Changes in the slope of the yield curve for short maturities therefore reflect changing perceptions of risk. We use the survey data to test directly the expectations hypothesis (without needing to impose the additional assumption of rational expectations) and we reject. it.

(3) Conclusion (2) implies that hypotheses which attempt to explain the bias in the spread at the short end of the maturity spectrum in terms of over- or underreaction receive no support in our tests. There is no evidence of systematic forecasting errors in the surveys. Our direct test of the overreaction hypothesis finds no evidence that expected short rate changes are excessively or insufficiently volatile.

(4) The brightest ray of hope for the expectations theory comes from expectations of future long-term bond rates. The survey data show that expected long-rate changes conform closely with the expectations theory in the sense that an increase in the spread is reflected in a onefor-one increase in the expected future long rate. This fact suggests that the frequently cited tendency of the spread to predict long rate changes perversely camnot be explained by errors made in measuring long-term rates, or by variation in term premia. Though the survey premium remains highly variable even after measurement errors are removed, we cannot reject the hypothesis that the true premium is uncorrelated with the spread. 
(5) Conclusion (4) implies that the inability of the spread to forecast future long rate changes is attributable primarily to systematic expectational errors. We cannot reject the hypothesis that the change in the long rate in excess of the spread is attributable exclusively to these expectational errors. More specifically, investors overreact to changes in the spread. Their expectations are excessively volatile, in that they would do better by moving their forecasts of the future long-rate in the direction of the contemporaneous short rate. Long rates, which under the expectations theory are a weighted average of expected future short rates, underreact to contemporaneous short rate changes. Mankiw and Summers (1984) and Campbell and Shiller (1984) also interpreted their results as evidence that long rates underreact; our evidence suggests that this result can no longer be attributed to the term premium.

(6) We also present evidence that expectations formation is very similar across countries. While the spread predicts future interest changes more poorly in the U.S. than in other countries, we cannot reject the hypothesis that this effect is attributable entirely to differences in the nature of expectational errors in the U.S. versus several other countries. The unique tendency for expected U.S. long rates to overreact to changes in the spread may be an indication that investors do not believe U.S. short rates are nearly nonstationary, as the post-war sample alone might lead one to conclude.

(7) Perceptions of risk tend to become increasingly important in the pricing of bonds as duration increases. We document large and statistically significant swings in term premia on long-term bonds, and substantially smaller (but nevertheless significant) swings on short-term bills. Investor perceptions of the risks of holding long-term bonds appear murh smoother than the predictable component of realized excess returns, but are measured much more precisely. In contrast to the behavior of predictable excess returns, these premia appear to be large when nominal interest and inflation rates are high. 


\section{References}

Campbell, J.Y., "A Defense of Traditional Hypotheses about the Term Structure of Interest Rates," Journal of Finance Vol XLI, pp. 183-193, 1986.

and R.J. Shiller, "A Simple Account of the Bchavior of Long-Term Interest Rates," American Economic Review, Vol 74, No. 2, pp. 44-48, 1984.

"Cointegration and Tests of Present Value Models," (forthcoming, Journal of Political Economy), 1987.

Cox, J.C., J.E. Ingersoll, Jr., and S.A. Ross, "A Re-examination of Traditional Hypotheses about the Term Structure of Interest Rates," Journal of Finance, Vol. XXXVI, pp. 769-799, 1985.

Engle, R.F., D.M. Lilien and R.P. Robins, "Estimating Time Varying Risk Premia in the Term Structure: The ARCH-M Model," University of California, San Diego, December 1984.

Fama, E.F., "Premiums in Bond Returns," Journal of Financial Economics, Vol. 13, pp. 529-546, 1984 a.

, "The Information in the Term Structure," Journal of Financial Economics, Vol. 13 , pp. 509-528, 1984 b.

Fama, E.F. and R.R. Bliss, "The Information in Long-Maturity Forward Rates," University of Chicago (forthcoming, American Economic Review) 1987.

Fama, E.F. and K.R. French, "Detecting Spot Price Forecasts in Futures Prices," Journal of Business Vol 59, No. 2, pp 39-54, 1986.

Friedman, B.M., "Interest Rate Expectations Versus Forward Rates: Evidence from an Expectations Survey," Journal of Finance, Vol. XXXIV, pp. 965-973, 1979.

"Survey Evidence on the 'Rationality" of Interest Rate Expectations," Journal of Monetary Economics, Vol. 6, pp. 453-465, 1980.

Froot, K.A., "Consistent Covariance Matrix Estimation with Cross-Sectional Dependence and Heteroskedasticity in Cross-Sectional Financial Data," Massachusetts Institute of Technology, 1987a.

"Testing for Excess Forecast Volatility in Asset Markets," Massachusetts Institute of Technology, $1987 \mathrm{~b}$.

Froot, K.A. and J.A. Frankel, "Interpreting Tests of Forward Discount Bias Using Survey Data on Exchange Rate Expectations," NBER Working Paper, no. 1963, 1986. 
Hansen, L.P., "Large Sample Properties of Generalized Method of Moments Estimators," Econometrica, Vol. 50, pp. 1029-1054, 1982.

Hodrick, R., and S. Srivastava, "An Investigation of Risk and Return in Forward Foreign Exchange," Journal of International Money and Finance, April 1984, 3, pp. 5-30.

"The Covariation of Risk Premiums and Expected Future Spot Rates," Journal of International Money and Finance, 1986.

Paper, no. , 1986.

Jones, D.S. and V.V. Roley, "Rational Expectations and the Expectations Model of the Term Structure," Journal of Monetary Economics, Vol. 12, pp. 453-465, 1983.

Macaulay, F.R., Some Theoretical Problems Suggested by Movements of Interest Rates, Bond Yields and Stock Prices in the United States Since 1856, New York, NBER, 1938.

Mankiw, N.G., "The Term Structure of Interest Rates Revisited," Brooking Papers on Economic Activity, Vol 1., pp. 61-110, 1986.

Mankiw, N.G. and J.A. Miron, ${ }^{\alpha}$ The Changing Behavior of the Term Structure of Interest Rates," Quarterly Journal of Economics, Vol. CI, pp. 211-228, 1986.

"A Resurrection of the Expectations Theory of the Term Structure," University of Michigan at Ann Arbor, 1986.

Mankiw, N.G. and L.H. Summers, "Do Long-Term Interest Rates Overreact to Short-Term Interest Rates?," Brookings Papers on Economic Activity, No. 1, pp. 223-242, 1984.

Modigliani, F. and R.J. Shiller, "Inflation, Rational Expertations and the Term Structure of Interest Rates," Economica pp. 12-43, 1973.

Newey, W., and K. West, "A Simple, Positive Definite, Heteroskedasticity and Autocorrelation Consistent Covariance Matrix," Woodrow Wilson School Discussion Paper, No. 92, May 1985.

Rubinstein, M., "An Aggregation Theorem for Securities Markets," Journal of Financial Economics, Vol. 1, pp. 225-244, 1974.

Shiller, R.J., "The Volatility of Long-Term Interest Rates and Expectations Models of the Term Structure," Journal of Political Economy, Vol. 87, no. 6, pp. 1190-1219, 1979.

"Alternative Tests of Rational Expectations Models: The Case of the Term Structure," Journal of Econometrics, Vol. 16, pp. 71-87, 1981. 
"The Term Structure of Interest Rates," forthcoming in the Handbook of Monetary Economics, North-Holland.

Shiller, R.J., J.Y. Campbell and K.L. Schoenholtz, "Forward Rates and Future Policy: Interpreting the Term Structure of Interest Rates," Brookings Papers on Economic Activity, No. 1, pp. 223-242, 1983.

Startz, R., "Do forecast errors or term premia really make the difference between long and short rates?," Journal of Financial Economics, Vol. 10, pp. 323-329, 1982.

White, H., "A Heteroskedasticity-Consistent Covariance Matrix Estimator and a Direct Test for Heteroskedasticity," Econometrica, vol. 48 no 4., pp. 817-838, 1980. 
Table 1

A Complete set of Tests of

The Bxpectations Hypothesis for

a Linearized lodel

Colvin A

Dependent Variable
Colyn $B$

Independent Variable
(1) $i_{t+j}^{k-j}-i_{t}^{j}$

(2) $i_{t+j}^{k-j}-i_{t}^{k}$

(3) $\quad i_{t+j}^{k-j}-f_{f}^{j, k-j}$

(4) $h_{t}^{k, j}-i_{t}^{j}$

(5) $h_{t}^{k, j}-i_{t}^{k}$
(1) $\frac{D_{k}}{D_{k}-D_{j}}\left(i_{t}^{k}-i_{t}^{j}\right)$

(2) $f_{t}^{j, i-j}-i_{t}^{j}$

(3) $\frac{D_{k}}{D_{j}}\left(f_{t}^{j, k-j}-1_{t}^{k}\right)$ 
Table $2 a$

Tests of the Ter structure of the $0 . S$.

ous legressions of

\begin{tabular}{|c|c|c|c|c|c|c|c|c|c|}
\hline $\begin{array}{c}\text { Instrusent } \\
(k-f)\end{array}$ & $\begin{array}{l}\text { Data Set: } \\
\text { Coldsith- } \\
\text { Magan Dates }\end{array}$ & $\begin{array}{l}\text { Forecast } \\
\text { forison } \\
\text { (j) }\end{array}$ & B & $t: \beta=1$ & Bcc & Din & $\overline{\mathbf{R}^{2}}$ & DF & $\begin{array}{l}\text { Fest } \\
=0 \\
p=1\end{array}$ \\
\hline$\frac{3 \text { Month }}{x \text { Bill }}$ & $\begin{array}{l}\text { 1969-1986 } \\
\text { quarterly }\end{array}$ & 3 Mns & $\begin{array}{c}0.0592 \\
(0.2602) \\
(0.2397)\end{array}$ & $\begin{array}{l}-3.616 \star \star \star \\
-3.925 * \star \star\end{array}$ & $\begin{array}{c}4.9737 \\
(0.8679) \\
(1.1277)\end{array}$ & 2.06 & .35 & 67 & $\begin{array}{l}14.37 \star \star \star \\
14.64 \star \star \star\end{array}$ \\
\hline $\begin{array}{l}\frac{3 \text { ronth }}{\text { Eure Dollar }} \\
\text { Eut }\end{array}$ & $\begin{array}{l}1969-1978 \\
\text { quarterly }\end{array}$ & 3 Mns & $\begin{array}{c}0.4267 \\
(0.3155) \\
(0.4744)\end{array}$ & $\begin{array}{l}-1.817^{\star} \\
-1.209\end{array}$ & NA & 1.89 & .02 & 33 & $\begin{array}{l}5.55 \star \star \star \\
3.28 \star\end{array}$ \\
\hline$\frac{12 \text { Month }}{2 \text { Bill }}$ & $\begin{array}{l}1969-1986 \\
\text { quarterly }\end{array}$ & 3 Mns & $\begin{array}{l}0.2909 \\
(0.1715) \\
(0.2412)\end{array}$ & $\begin{array}{l}-4.134 * \star \star \\
-2.939 * \star \star\end{array}$ & $\begin{array}{c}2.0542 \\
(0.4861) \\
(0.9818)\end{array}$ & 2.13 & .27 & 67 & $\begin{array}{l}19.73 \star \star \star \\
23.31 \star \star \star\end{array}$ \\
\hline $\begin{array}{l}\text { Buyer Bond } \\
\text { Inder }\end{array}$ & $\begin{array}{l}1969-1986 \\
\text { quarter } 1 y\end{array}$ & 3 Mns & $\begin{array}{c}0.8342 \\
(0.0474) \\
(0.0416)\end{array}$ & $\begin{array}{l}-3.497 \star \star \star \\
-3.988 * \star \star\end{array}$ & $\begin{array}{c}0.1576 \\
(0.0927) \\
(0.2200)\end{array}$ & 2.37 & .87 & 67 & $\begin{array}{l}4.09 * \star \\
5.31 * \star \star\end{array}$ \\
\hline$\frac{30 \text { Rear }}{\text { Yortanoies }}$ & $\begin{array}{l}1969-1986 \\
\text { quarter } 1 y\end{array}$ & 3 Mns & $\begin{array}{c}0.7568 \\
(0.0690) \\
(0.1101)\end{array}$ & $\begin{array}{l}-3.523^{\star \star \star} \\
-2.208^{\star \star}\end{array}$ & $\begin{array}{c}0.4209 \\
(0.1275) \\
(0.2193)\end{array}$ & 2.74 & .69 & 67 & $\begin{array}{l}6.58 \star \star \star \\
5.26 \star \star \star\end{array}$ \\
\hline$\frac{3 \text { Yonth }}{1 \text { Bill }}$ & $\begin{array}{l}1969-1986 \\
\text { quarterly }\end{array}$ & 6 Mns & $\begin{array}{l}-0.3626 \\
(0.3347) \\
(0.3055)\end{array}$ & $\begin{array}{l}-4.071 * \star \star \\
-4.460 * \star \star\end{array}$ & $\begin{array}{c}0.9284 \\
(0.7482) \\
(1.7105)\end{array}$ & 1.79 & .01 & 66 & $\begin{array}{l}15.04 \star \star \star \\
13.32 \star \star \star\end{array}$ \\
\hline$\frac{12 \text { Fonth }}{1 \text { Bill }}$ & $\begin{array}{l}1969-1986 \\
\text { quarter } 1 y\end{array}$ & 6 ins & $\begin{array}{l}-0.1219 \\
(0.2088) \\
(0.2360)\end{array}$ & $\begin{array}{l}-5.374 \star \star \star \\
-4.755 \star \star \star\end{array}$ & $\begin{array}{c}2.3456 \\
(0.5963) \\
(0.8378)\end{array}$ & 1.51 & .18 & 66 & $\begin{array}{l}22.29 \star \star \star \\
20.93 \star \star \star\end{array}$ \\
\hline $\begin{array}{l}\text { Buyer Bond } \\
\text { Index }\end{array}$ & $\begin{array}{l}1969-1986 \\
\text { quarter } 1 y\end{array}$ & 6 Mns & $\begin{array}{c}0.6355 \\
(0.0711) \\
(0.0748)\end{array}$ & $\begin{array}{l}-5.127 \star \star \star \\
-4.875 * \star \star\end{array}$ & $\begin{array}{c}0.2946 \\
(0.1317) \\
(0.0984)\end{array}$ & 1.29 & .71 & 66 & $\begin{array}{l}8.85 * k \star \\
9.03 * \star \star\end{array}$ \\
\hline$\frac{30 \text { Yenr }}{\text { Mortances }}$ & $\begin{array}{l}1969-1986 \\
\text { quarterly }\end{array}$ & 6 Mns & $\begin{array}{c}0.5680 \\
(0.0897) \\
(0.0936)\end{array}$ & $\begin{array}{l}-4.819 * \star \star \\
-4.614 * t \star\end{array}$ & $\begin{array}{c}0.4355 \\
(0.1552) \\
(0.1261)\end{array}$ & 1.53 & .47 & 66 & $\begin{array}{r}9.15 \star \star \star \\
11.58 \star \star \star\end{array}$ \\
\hline
\end{tabular}

Notes: Standard errors (in parentheses) are computed using Gar under the assumption of homoskedasticity and also allowing for conditional heteroskedasticity, respectively.

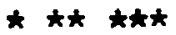


Tints 2b

Tests of the Tern structure of Various Countries

Gis Regressions of

$$
i_{t+j}^{k-j}-i_{t}^{j}=\alpha+\beta\left(f_{t}^{i, k-j}-i_{t}\right)+\varepsilon_{t+j}
$$

\begin{tabular}{|c|c|c|c|c|c|c|c|c|}
\hline $\begin{array}{l}\text { Country } \\
\text { Instrument } \\
(\mathbf{k}-\mathbf{j})\end{array}$ & $\begin{array}{l}\text { Data get } \\
\text { Dates }\end{array}$ & $\begin{array}{l}\text { Forecast } \\
\text { fortson } \\
\text { (j) }\end{array}$ & B & $t: \beta=1$ & DN & $\vec{R}^{2}$ & DF & $\begin{array}{c}\text { Fest } \\
a=0 \\
\beta=1\end{array}$ \\
\hline 3 MS & $\begin{array}{c}\text { MMS } \\
1 / 83-10 / 84 \\
\text { biweekly }\end{array}$ & 3 Mns & $\begin{array}{l}-0.9269 \\
(0.7815) \\
(0.2813)\end{array}$ & $\begin{array}{l}-2.469 \star \star \\
-6.858 \star \star \star\end{array}$ & 0.15 & .04 & 45 & $\begin{array}{c}4.72^{\star \star} \\
24.43^{\star \star \star}\end{array}$ \\
\hline $\begin{array}{l}\text { West Germany } \\
3 \text { Month Euro Dm }\end{array}$ & $\begin{array}{c}\text { MMS } \\
1 / 83-10 / 84 \\
\text { biweekly }\end{array}$ & 3 Mns & $\begin{array}{c}0.4378 \\
(0.2443) \\
(0.1851)\end{array}$ & $\begin{array}{l}-2.301 \star \star \\
-3.038 \star \star \star\end{array}$ & 0.64 & .09 & 45 & $\begin{array}{l}11.95^{\star \star \star \star} \\
11.88^{\star \star \star \star}\end{array}$ \\
\hline $\begin{array}{l}\text { England } \\
3 \text { Month Euro Pound }\end{array}$ & $\begin{array}{c}\text { Mus } \\
1 / 83-10 / 84 \\
\text { biweekly }\end{array}$ & 3 Mns & $\begin{array}{l}1.5581 \\
(0.4255) \\
(0.5881)\end{array}$ & $\begin{array}{l}1.312 \\
0.949\end{array}$ & 0.82 & .30 & 45 & $\begin{array}{l}2.28 \\
14.23 \star \star \star\end{array}$ \\
\hline $\begin{array}{l}\text { Japan } \\
3 \text { Month Euro Yen }\end{array}$ & $\begin{array}{c}\text { Mys } \\
1 / 83-10 / 84 \\
\text { biweekly }\end{array}$ & 3 Mns & $\begin{array}{l}0.5123 \\
(0.2258) \\
(0.1414)\end{array}$ & $\begin{array}{l}-2.160 \star \star \\
-3.449 \star \star \star\end{array}$ & 0.59 & .13 & 45 & $\begin{array}{l}3.24^{\star \star} \\
11.74^{\star \star \star}\end{array}$ \\
\hline $\begin{array}{l}\text { Australia } \\
10 \text { Year Treasury } \\
\text { Bonds }\end{array}$ & $\begin{array}{c}\text { Miss } \\
2 / 85-2 / 87 \\
\text { weekly }\end{array}$ & $1 \mathrm{Mn}$ & $\begin{array}{l}1.2679 \\
(0.0695) \\
(0.0870)\end{array}$ & $\begin{array}{l}3.854 \star \star \star \\
3.078 \star \star \star\end{array}$ & 0.91 & .87 & 71 & $\begin{array}{l}8.00 \star \star \star \\
5.76 \star \star \star\end{array}$ \\
\hline
\end{tabular}

Notes: Standard errors (in parentheses) are computed using GM under the assumption of homoskedastlcity and also allowing for conditional heteroskedasticity, respectively. $\star, \star \star, \star \star \star$ represent significance at the 10,5 and 1 percent levels, respectively. 


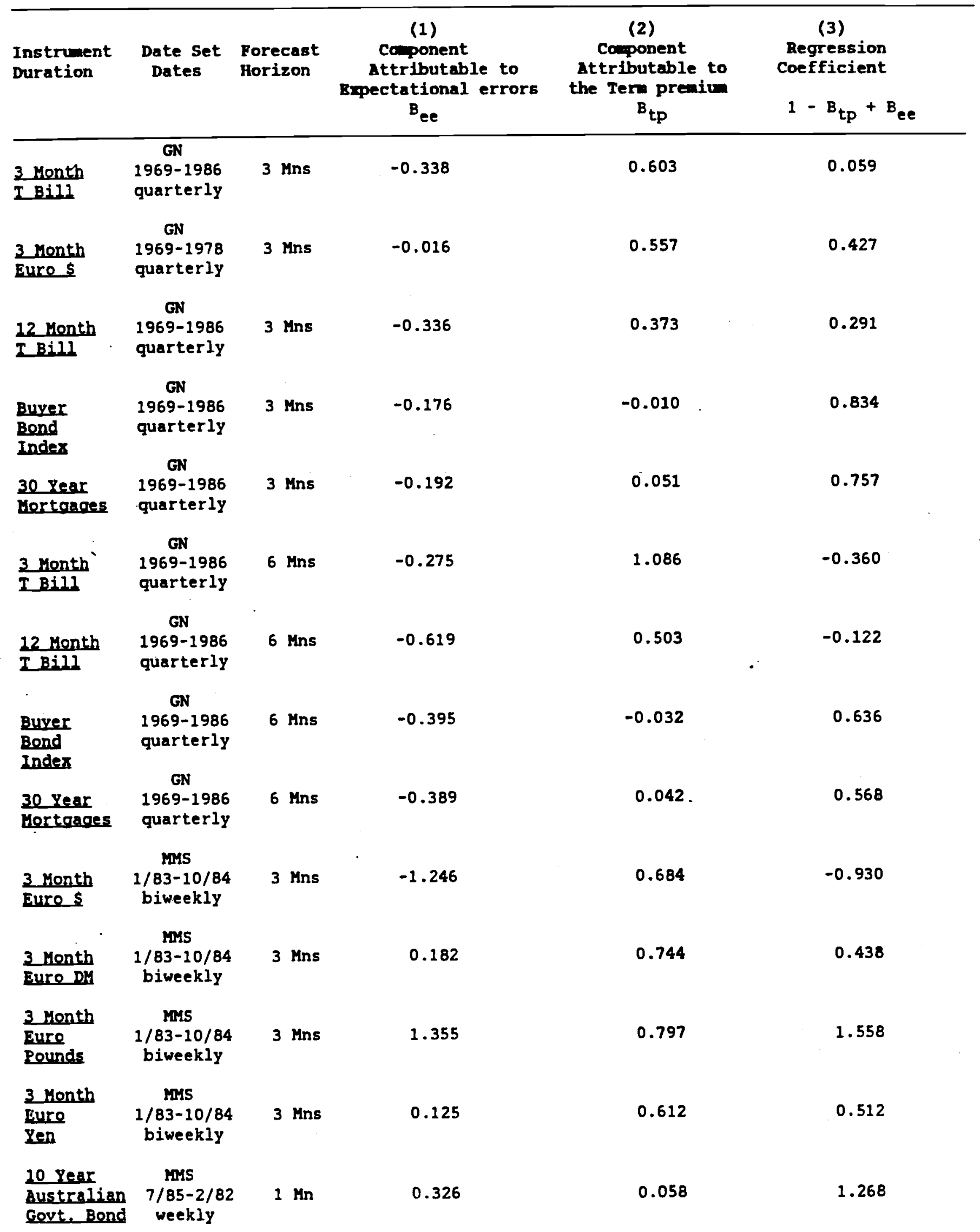


Table $4 a$

Tests of the expectations Fypothesis in the $0 . S$. Term Structure ous Regressions of

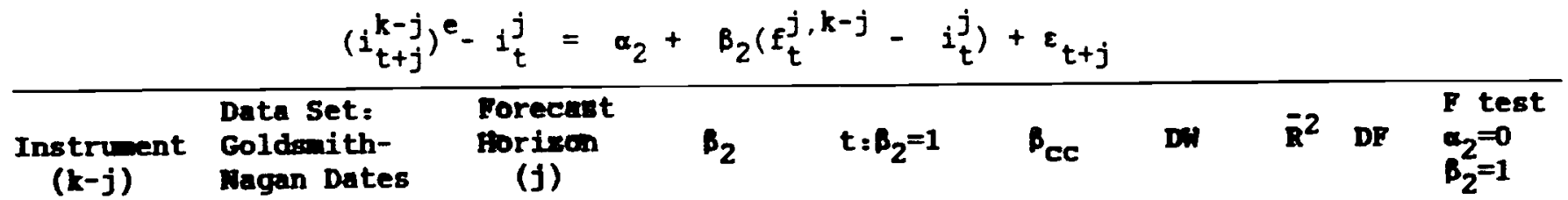

\begin{tabular}{|c|c|c|c|c|c|c|c|c|c|}
\hline$\frac{3 \text { Month }}{2 \text { Bill }}$ & $\begin{array}{l}1969-1986 \\
\text { quarterly }\end{array}$ & 3 Mns & $\begin{array}{c}0.3974 \\
(0.1011) \\
(0.1825)\end{array}$ & $\begin{array}{l}-5.958 \star \star \star \\
-3.302^{\star \star \star}\end{array}$ & $\begin{array}{c}0.5715 \\
(0.2946) \\
(0.3443)\end{array}$ & 0.66 & .31 & 67 & $\begin{array}{l}23.29 \star \star \star \\
13.83 \star \star \star\end{array}$ \\
\hline
\end{tabular}

\begin{tabular}{|c|c|c|c|c|c|c|c|c|c|}
\hline$\frac{3 \text { Honth }}{\text { Euro Dollar }}$ & $\begin{array}{l}1969-1978 \\
\text { quarterly }\end{array}$ & $3 \mathrm{Mns}$ & $\begin{array}{c}0.4428 \\
(0.1404) \\
(0.1118)\end{array}$ & $\begin{array}{l}-3.968 \star \star \star \star \\
-4.984 \star \star \star\end{array}$ & NA & 0.57 & .28 & 33 & $\begin{array}{l}34.23 * \star \star \\
18.70 * \star \star\end{array}$ \\
\hline
\end{tabular}

\begin{tabular}{|c|c|c|c|c|c|c|c|c|c|}
\hline $\begin{array}{l}12 \text { Yonth } \\
\text { I Bill }\end{array}$ & $\begin{array}{l}1969-1986 \\
\text { quarterly }\end{array}$ & $3 \mathrm{Mns}$ & $\begin{array}{c}0.6273 \\
(0.1164) \\
(0.1432)\end{array}$ & $\begin{array}{l}-3.203 \star \star \star \\
-2.603 \star \star \star\end{array}$ & $\begin{array}{c}0.0773 \\
(0.2583) \\
(0.3102)\end{array}$ & 0.47 & .44 & & $67 \begin{array}{l}20.01 \star \star \star \star \\
16.12^{\star \star \star}\end{array}$ \\
\hline
\end{tabular}

\begin{tabular}{|c|c|c|c|c|c|c|c|c|c|}
\hline $\begin{array}{l}\text { Buyer Bond } \\
\text { Index }\end{array}$ & $\begin{array}{l}\text { 1969-1986 } \\
\text { quarterly }\end{array}$ & $3 \mathrm{Mns}$ & $\begin{array}{l}1.0100 \\
(0.0276) \\
(0.0287)\end{array}$ & $\begin{array}{l}0.364 \\
0.350\end{array}$ & $\begin{array}{l}-0.0024 \\
(0.0463) \\
(0.0327)\end{array}$ & 1.01 & .98 & 67 & $\begin{array}{l}0.76 \\
3.64 \star \star\end{array}$ \\
\hline$\frac{30 \text { Year }}{\text { Bortgages }}$ & $\begin{array}{l}1969-1986 \\
\text { quarterly }\end{array}$ & $3 \mathrm{Mns}$ & $\begin{array}{c}0.9493 \\
(0.0329) \\
(0.0310)\end{array}$ & $\begin{array}{l}-1.541 \\
-1.636\end{array}$ & $\begin{array}{l}-0.1288 \\
(0.0565) \\
(0.0346)\end{array}$ & 0.64 & .95 & 67 & $\begin{array}{r}8.88 \star \star \star \star \\
48.27 \star \star \star\end{array}$ \\
\hline
\end{tabular}

\begin{tabular}{|c|c|c|c|c|c|c|c|c|c|}
\hline$\frac{3 \text { ronth }}{\text { I Bill }}$ & $\begin{array}{l}1969-1986 \\
\text { quarterly }\end{array}$ & 6 Mns & $\begin{array}{l}-0.0858 \\
(0.1302) \\
(0.1613)\end{array}$ & $\begin{array}{l}-8.337 \star \star \star \\
-6.730 \star \star \star\end{array}$ & $\begin{array}{l}-0.7207 \\
(0.2856) \\
(0.3189)\end{array}$ & 1.00 & .1 & & $67 \begin{array}{l}72.83 \star \star \star \\
97.12^{\star \star \star}\end{array}$ \\
\hline
\end{tabular}

\begin{tabular}{|c|c|c|c|c|c|c|c|c|c|c|}
\hline $\begin{array}{l}12 \text { Month } \\
\text { I Bild }\end{array}$ & $\begin{array}{l}1969-1986 \\
\text { quarterly }\end{array}$ & 6 Mns & $\begin{array}{c}0.4974 \\
(0.1256) \\
(0.1437)\end{array}$ & $\begin{array}{l}-4.001 * \star \star \\
-3.499 \star \star \star\end{array}$ & $\begin{array}{l}-0.1243 \\
(0.3041) \\
(0.2149)\end{array}$ & 0.56 & .2 & & 67 & $\begin{array}{l}24.12^{\star \star \star \star} \\
22.97^{\star \star \star}\end{array}$ \\
\hline
\end{tabular}

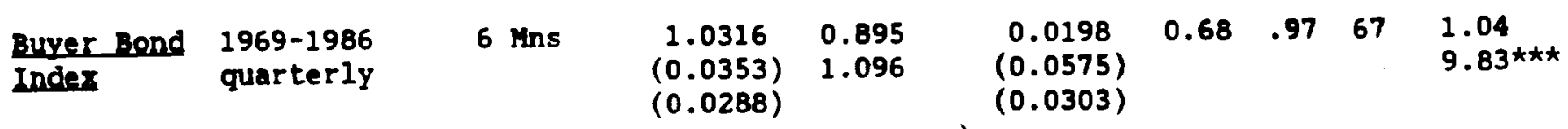

\begin{tabular}{|c|c|c|c|c|c|c|c|c|c|}
\hline$\frac{30 \text { Year }}{\text { Vortgages }}$ & $\begin{array}{l}1969-1986 \\
\text { quarterly }\end{array}$ & 6 Mns & $\begin{array}{c}0.9576 \\
(0.0485) \\
(0.0488)\end{array}$ & $\begin{array}{l}-0.874 \\
-0.869\end{array}$ & $\begin{array}{l}-0.1925 \\
(0.0807) \\
(0.0597)\end{array}$ & 0.60 & .90 & 67 & $\begin{array}{r}8.69 \star \star \star \star \\
23.76 \star t \star\end{array}$ \\
\hline
\end{tabular}

Notes: Standard errors (in parentheses) are computed using Gar under the assumptjon of homoskedasticity and also allowing for conditional heteroskedasticity, respectively. $\star, \star \star, \star \star \star \star 丿$ represent significance at the 10,5 and 1 percent levels, respectively. 


\section{Tabts $4 b$}

Tests of the Epectations Hypothesis in Various Countries

oLs Regressions of

$$
\left(i_{t+j}^{k-j}\right)^{e}-i_{t}^{j}=\alpha_{2}+\beta_{2}\left(f_{t}^{i, k-j}-i_{t}\right)+\varepsilon_{t+j}
$$

\begin{tabular}{|c|c|c|c|c|c|c|c|c|}
\hline $\begin{array}{l}\text { Country } \\
\text { Instrument } \\
(k-j)\end{array}$ & $\begin{array}{l}\text { Data set } \\
\text { Dates }\end{array}$ & $\begin{array}{l}\text { Forecast } \\
\text { Horison } \\
(J)\end{array}$ & $B_{2}$ & $t: B_{2}=1$ & D & $\mathrm{A}^{2}$ & DF & $\begin{array}{c}\text { P Test } \\
a_{2}=0 \\
B_{2}=1\end{array}$ \\
\hline$\frac{\text { US }}{3 \text { Month Euro } s}$ & $\begin{array}{c}\text { MMS } \\
1 / 83-10 / 84 \\
\text { biweek1y }\end{array}$ & $3 \mathrm{Mns}$ & $\begin{array}{c}0.3165 \\
(0.0752) \\
(0.0496)\end{array}$ & $\begin{array}{r}-9.083 \star \star \star \\
-13.768 * \star \star\end{array}$ & 0.97 & .27 & 45 & $\begin{array}{l}378.28 \star \star \star \\
468.25 \star \star \star\end{array}$ \\
\hline $\begin{array}{l}\text { West Germany } \\
3 \text { Month Euro Dm }\end{array}$ & $\begin{array}{c}\text { MMS } \\
1 / 83-10 / 84 \\
\text { biweek1y }\end{array}$ & 3 kns & $\begin{array}{c}0.2562 \\
(0.1006) \\
(0.1006)\end{array}$ & $\begin{array}{l}-7.392 \star \star \star \\
-7.396 \star \star \star\end{array}$ & 1.87 & .11 & 45 & $\begin{array}{l}154.80^{\star \star \star} \\
810.54 \star \star \star\end{array}$ \\
\hline $\begin{array}{l}\text { England } \\
3 \text { Month Euro Pound }\end{array}$ & $\begin{array}{c}\text { Mus } \\
1 / 83-10 / 84 \\
\text { biweek } 1 Y\end{array}$ & 3 Mns & $\begin{array}{c}0.2031 \\
(0.0712) \\
(0.0484)\end{array}$ & $\begin{array}{l}-11.198 \star \star \star \star \\
-16.421 \star \star \star\end{array}$ & 1.19 & .13 & 45 & $\begin{array}{r}89.66 \star \star \star \star \\
201.51 \star \star \star\end{array}$ \\
\hline $\begin{array}{l}\text { Japan } \\
3 \text { Month Euro Yen }\end{array}$ & $\begin{array}{c}\text { Mis } \\
1 / 83-10 / 84 \\
\text { biweekly }\end{array}$ & 3 Mns & $\begin{array}{c}0.3876 \\
(0.1236) \\
(0.1400)\end{array}$ & $\begin{array}{l}-4.955 \star \star \star \\
-4.374^{\star \star \star}\end{array}$ & 1.63 & .16 & 45 & $\begin{array}{l}58.19 \star \star \star \star \\
58.26 \star \star \star\end{array}$ \\
\hline $\begin{array}{l}\text { Australio } \\
10 \text { Year Treasury } \\
\text { Bonds }\end{array}$ & $\begin{array}{c}\text { MHS } \\
2 / 85-2 / 87 \\
\text { week1y }\end{array}$ & $1 \mathrm{Mn}$ & $\begin{array}{l}0.9419 \\
(0.0148) \\
(0.0194)\end{array}$ & $\begin{array}{l}-3.928 \star \star \star \\
-3.003 \star \star \star\end{array}$ & 1.88 & .99 & 71 & $\begin{array}{l}8.31 * t \star \\
5.05^{\star \star \star \star}\end{array}$ \\
\hline
\end{tabular}

Notes: Standard errors (in parentheses) are computed using GMM under the assumption of

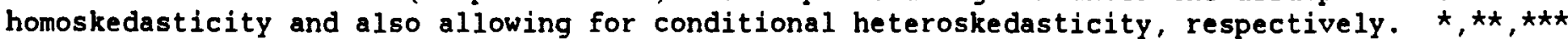
represent significance at the 10,5 and 1 percent levels, respectively. 
Tests of Excessive Forecast Polatility in the O.S. Term Structure OLS Regressions of

$$
i_{t+j}^{k-j}-\left(\frac{k-j}{t+j}\right)^{e}=a_{3}+B_{3}\left(\left(i_{t+j}^{k-j} e\right)-i_{t}^{j}\right)+\varepsilon_{t+j}
$$

\begin{tabular}{|c|c|c|c|c|c|c|c|c|c|}
\hline $\begin{array}{l}\text { Instrument } \\
(k-j)\end{array}$ & $\begin{array}{l}\text { Data set: } \\
\text { Colds:ith- } \\
\text { magan Dates }\end{array}$ & $\begin{array}{l}\text { Forecast } \\
\text { Porison } \\
\text { (j) }\end{array}$ & $B_{3}$ & $t: B_{3}=0$ & $B_{c c}$ & DN & $\overrightarrow{\mathbf{R}^{2}}$ & DF & $\begin{array}{l}\text { Ftest } \\
a_{3}=0 \\
B_{3}=0\end{array}$ \\
\hline$\frac{3 \text { Month }}{I \text { Bill }}$ & $\begin{array}{l}1969-1986 \\
\text { quarterly }\end{array}$ & 3 Mns & $\begin{array}{l}-0.6380 \\
(0.3715) \\
(0.2575)\end{array}$ & $\begin{array}{l}-1.718 \star \\
-2.478 \star \star\end{array}$ & $\begin{array}{l}-2.2337 \\
(0.8130) \\
(1.8396)\end{array}$ & 2.22 & .08 & 67 & $\begin{array}{l}2.62 \star \\
2.31 \star\end{array}$ \\
\hline$\frac{3 \text { Month }}{\text { Eure Dolyar }}$ & $\begin{array}{l}1969-1978 \\
\text { quarterly }\end{array}$ & 3 Mns & $\begin{array}{l}-0.0476 \\
(0.3675) \\
(0.6820)\end{array}$ & $\begin{array}{l}-0.130 \\
-0.070\end{array}$ & NA & 1.84 & .00 & 33 & $\begin{array}{l}0.60 \\
0.34\end{array}$ \\
\hline$\frac{12 \text { Month }}{2 \text { Bill }}$ & $\begin{array}{l}1969-1986 \\
\text { quarterly }\end{array}$ & 3 Mns & $\begin{array}{l}-0.5324 \\
(0.1760) \\
(0.2040)\end{array}$ & $\begin{array}{l}-3.025^{\star \star \star} \\
-2.610^{\star \star}\end{array}$ & $\begin{array}{l}1.8475 \\
(0.3968) \\
(0.7746)\end{array}$ & 2.35 & .23 & 67 & $\begin{array}{l}7.48 \star \star \star \\
3.28 \star \star\end{array}$ \\
\hline $\begin{array}{l}\text { Buyer Bond } \\
\text { Index }\end{array}$ & $\begin{array}{l}1969-1986 \\
\text { quarterly }\end{array}$ & 3 Mns & $\begin{array}{l}-0.1958 \\
(0.0500) \\
(0.0495)\end{array}$ & $\begin{array}{l}-3.916 \star \star \star \\
-3.954 * \star \star\end{array}$ & $\begin{array}{c}0.1656 \\
(0.0978) \\
(0.2133)\end{array}$ & 2.23 & .16 & 67 & $\begin{array}{l}5.48 \star \star \star \\
5.26 \star \star \star\end{array}$ \\
\hline$\frac{30 \text { Year }}{\text { Yortonges }}$ & $\begin{array}{l}1969-1986 \\
\text { quarterly }\end{array}$ & 3 Mns & $\begin{array}{l}-0.2513 \\
(0.0708) \\
(0.1090)\end{array}$ & $\begin{array}{l}-3.548 \star \star \star \\
-2.305 \star \star\end{array}$ & $\begin{array}{c}0.7366 \\
(0.1540) \\
(0.2275)\end{array}$ & 2.43 & .29 & 67 & $\begin{array}{r}11.15^{\star \star \star \star} \\
5.94^{\star \star \star}\end{array}$ \\
\hline$\frac{3 \text { Bonth }}{T \text { Bill }}$ & $\begin{array}{l}1969-1986 \\
\text { quarterly }\end{array}$ & 6 Mns & $\begin{array}{l}-0.3188 \\
(0.3701) \\
(0.2671)\end{array}$ & $\begin{array}{l}-0.861 \\
-1.194\end{array}$ & $\begin{array}{l}0.6412 \\
(0.6564) \\
(0.6252)\end{array}$ & 1.41 & .00 & 66 & $\begin{array}{l}0.44 \\
0.63\end{array}$ \\
\hline$\frac{12 \text { Honth }}{\text { I Bill }}$ & $\begin{array}{l}1969-1986 \\
\text { quarterly }\end{array}$ & 6 Mns & $\begin{array}{l}-0.5517 \\
(0.2550) \\
(0.2127)\end{array}$ & $\begin{array}{l}-2.163 \star \star \\
-2.594 \star \star\end{array}$ & $\begin{array}{l}1.3649 \\
(0.4846) \\
(0.3197)\end{array}$ & 1.26 & .10 & 66 & $\begin{array}{c}2.91 * \star \\
10.28 * \star \star\end{array}$ \\
\hline $\begin{array}{l}\text { Buyer Bond } \\
\text { Inder } \\
30 \text { Year } \\
\text { Bonds }\end{array}$ & $\begin{array}{l}1969-1986 \\
\text { quarterly }\end{array}$ & 6 Mns & $\begin{array}{l}-0.3967 \\
(0.0696) \\
(0.0743)\end{array}$ & $\begin{array}{l}-5.702^{\star \star \star} \\
-5.335^{\star \star \star}\end{array}$ & $\begin{array}{c}0.2526 \\
(0.1281) \\
(0.0982)\end{array}$ & 1.32 & .36 & 66 & $\begin{array}{l}11.46 \star \star \star \\
14.22 \star \star \star\end{array}$ \\
\hline$\frac{30 \text { Year }}{\text { Mortonoes }}$ & $\begin{array}{l}1969-1986 \\
\text { quarterly }\end{array}$ & 6 Mns & $\begin{array}{l}-0.4876 \\
(0.0903) \\
(0.0989)\end{array}$ & $\begin{array}{l}-5.399 \star \star \star \\
-4.930 \star \star \star\end{array}$ & $\begin{array}{c}0.8283 \\
(0.2023) \\
(0.0696)\end{array}$ & 1.49 & .38 & 66 & $\begin{array}{l}13.93^{\star \star \star} \\
67.71 \star \star \star\end{array}$ \\
\hline
\end{tabular}

Notes: Standard errors (in parentheses) are computed using Gan under the assumption of homoskedasticity and also allowing for conditional heteroskedasticity, respectively.

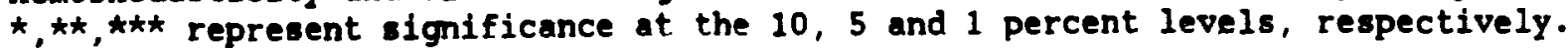


Thors 5b

\section{Tests of Eacessive Forecast Volatility \\ in The Tern structure of \\ various countries}

$$
i_{t+j}^{k-j}-\left(i_{t+j}^{k-j}\right)^{e}=\alpha_{3}+\beta_{3}\left(\left(i_{t+j}^{k-j}\right)^{e}-i_{t}\right)+\varepsilon_{t+j}
$$

\begin{tabular}{|c|c|c|c|c|c|c|c|c|}
\hline $\begin{array}{l}\text { Country } \\
\text { Instrument } \\
(k-j)\end{array}$ & $\begin{array}{c}\text { Data set } \\
\text { Dates }\end{array}$ & $\begin{array}{l}\text { Forecast } \\
\text { Forison } \\
(f)\end{array}$ & $B_{3}$ & $t: B_{3}=0$ & DA & $\bar{R}^{2}$ & DF & $\begin{array}{c}F \text { Test } \\
\alpha_{3}=0 \\
\beta_{3}=0\end{array}$ \\
\hline$\frac{\text { US }}{3 \text { Month Euro } 5}$ & $\begin{array}{c}\text { MMS } \\
1 / 83-10 / 84 \\
\text { biweekly }\end{array}$ & 3 Mns & $\begin{array}{l}-4.8147 \\
(1.0332) \\
(1.0404)\end{array}$ & $\begin{array}{l}-4.660 \star \star \star \star \\
-4.628 \star \star \star\end{array}$ & 0.50 & .48 & 45 & $\begin{array}{l}10.94^{\star \star \star} \\
24.12^{\star \star \star}\end{array}$ \\
\hline$\frac{\text { West Germany }}{3 \text { Month Euro Dm }}$ & $\begin{array}{c}\text { MMS } \\
1 / 83-10 / 84 \\
\text { biweekly }\end{array}$ & $3 \mathrm{Mns}$ & $\begin{array}{l}-0.8265 \\
(0.3085) \\
(0.2434)\end{array}$ & $\begin{array}{l}-2.679 \star \star \\
-3.396 \star \star \star\end{array}$ & 0.59 & .15 & 45 & $\begin{array}{l}4.41 \star \star \\
6.04 \star \star \star\end{array}$ \\
\hline $\begin{array}{l}\text { England } \\
3 \text { Month Euro Pound }\end{array}$ & $\begin{array}{c}\text { MMS } \\
1 / 83-10 / 84 \\
\text { biweekly }\end{array}$ & 3 Mns & $\begin{array}{c}0.4401 \\
(0.8960) \\
(0.6744)\end{array}$ & $\begin{array}{l}0.491 \\
0.653\end{array}$ & 0.57 & .00 & 45 & $\begin{array}{l}0.23 \\
0.54\end{array}$ \\
\hline $\begin{array}{l}\text { Japan } \\
3 \text { Month Euro Yen }\end{array}$ & $\begin{array}{c}\text { MS } \\
1 / 83-10 / 84 \\
\text { biweekly }\end{array}$ & 3 Mns & $\begin{array}{l}-0.7642 \\
(0.2482) \\
(0.3649)\end{array}$ & $\begin{array}{l}-3.081 \star \star \star \\
-2.096 \star \star\end{array}$ & 0.64 & .20 & 45 & $\begin{array}{l}8.86 \star \star \star \\
4.60 \star \star \star\end{array}$ \\
\hline $\begin{array}{l}\text { Australia } \\
10 \text { Year Treasury } \\
\text { Bonds }\end{array}$ & $\begin{array}{c}\text { MMS } \\
2 / 85-2 / 87 \\
\text { weekly }\end{array}$ & $1 \mathrm{Mn}$ & $\begin{array}{c}0.3353 \\
(0.0731) \\
(0.0995)\end{array}$ & $\begin{array}{l}4.588 \star \star \star \star \\
3.369 \star \star \star\end{array}$ & 0.95 & .29 & 71 & $\begin{array}{r}11.35^{\star \star \star} \\
7 \cdot 13^{\star \star \star}\end{array}$ \\
\hline
\end{tabular}

Notes: Standard errors (in parentheses) are computed using Gm under the assumption of homoskedasticity and also allowing for conditional heteroskedasticity, respectively. $\star, \star \star, \star \star \star$ represent significance at the 10,5 and 1 percent levels, respectively. 


\section{Table 6a}

Tests of Rational Epectations in the U.S. Tere structure OLS Regressions of

\begin{tabular}{|c|c|c|c|c|c|c|c|c|c|}
\hline $\begin{array}{c}\text { Instrument } \\
(k-j)\end{array}$ & $\begin{array}{l}\text { Data Set: } \\
\text { Goldsuith- } \\
\text { Nagan Dates }\end{array}$ & $\begin{array}{l}\text { Porecest } \\
\text { Aorizon } \\
\text { (J) }\end{array}$ & $B_{4}$ & $t: B_{4}=0$ & $B_{c c}$ & DH & $\overline{\mathbf{R}}^{2}$ & DF & $\begin{array}{c}F \text { test } \\
a_{4}=0 \\
B_{4}=1\end{array}$ \\
\hline$\frac{3 \text { Month }}{T \text { Bill }}$ & $\begin{array}{l}1969-1986 \\
\text { quarter1y }\end{array}$ & $3 \mathrm{Mns}$ & $\begin{array}{l}-0.3382 \\
(0.2696) \\
(0.2461)\end{array}$ & $\begin{array}{l}-1.255 \\
-1.374\end{array}$ & $\begin{array}{c}4.4022 \\
(0.8993) \\
(1.0817)\end{array}$ & 2.07 & .24 & 67 & $\begin{array}{l}8.09 * t \star \\
6.53 * t \star\end{array}$ \\
\hline$\frac{3 \text { Month }}{\text { Euro Dollar }}$ & $\begin{array}{l}1969-1978 \\
\text { quarterly }\end{array}$ & $3 \mathrm{Mns}$ & $\begin{array}{l}-0.0161 \\
(0.2955) \\
(0.4417)\end{array}$ & $\begin{array}{l}-0.054 \\
-0.036\end{array}$ & NA & 1.83 & .00 & 33 & $\begin{array}{l}0.59 \\
0.30\end{array}$ \\
\hline$\frac{12 \text { Month }}{1 \text { Bill }}$ & $\begin{array}{l}1969-1986 \\
\text { quarterly }\end{array}$ & $3 \mathrm{Mns}$ & $\begin{array}{l}-0.3363 \\
(0.1522) \\
(0.2203)\end{array}$ & $\begin{array}{l}-2.209 \star \star \\
-1.527\end{array}$ & $\begin{array}{l}1.9769 \\
(0.4314) \\
(0.7326)\end{array}$ & 2.44 & .22 & 67 & $\begin{array}{l}7.27 \star \star \star \\
6.06 \star \star \star\end{array}$ \\
\hline $\begin{array}{l}\text { Buyer Bond } \\
\text { Index }\end{array}$ & $\begin{array}{l}1969-1986 \\
\text { quarter ly }\end{array}$ & $3 \mathrm{Mns}$ & $\begin{array}{l}-0.1759 \\
(0.0526) \\
(0.0524)\end{array}$ & $\begin{array}{l}-3.345 \star \star \star \\
-3.356 \star \star \star\end{array}$ & $\begin{array}{c}0.1600 \\
(0.1029) \\
(0.2156)\end{array}$ & 2.11 & .12 & 67 & $\begin{array}{l}4.05 \star \star \\
3.87 \star \star\end{array}$ \\
\hline$\frac{30 \text { Year }}{\text { Mortgages }}$ & $\begin{array}{l}1969-1986 \\
\text { quarterly }\end{array}$ & 3 Mns & $\begin{array}{l}-0.1925 \\
(0.0727) \\
(0.1076)\end{array}$ & $\begin{array}{l}-2.647 \star \star \star \\
-1.789 \star\end{array}$ & $\begin{array}{c}0.5500 \\
(0.1344) \\
(0.1934)\end{array}$ & 2.42 & .21 & 67 & $\begin{array}{l}7.50 \star \star \star \\
3.63 \star \star\end{array}$ \\
\hline$\frac{3 \text { Month }}{\text { T Bill }}$ & $\begin{array}{l}1969-1986 \\
\text { quarterly }\end{array}$ & 6 Mns & $\begin{array}{l}-0.2746 \\
(0.3179) \\
(0.2928)\end{array}$ & $\begin{array}{l}-0.864 \\
-0.938\end{array}$ & $\begin{array}{l}1.6503 \\
(0.7109) \\
(1.3828)\end{array}$ & 1.73 & .06 & 66 & $\begin{array}{l}1.91 \\
0.84\end{array}$ \\
\hline 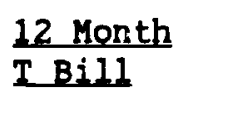 & $\begin{array}{l}1969-1986 \\
\text { quarterly }\end{array}$ & $6 \mathrm{Mns}$ & $\begin{array}{l}-0.6193 \\
(0.1706) \\
(0.1823)\end{array}$ & $\begin{array}{l}-3.631 \star \star \star \\
-3.400 \star \star \star\end{array}$ & $\begin{array}{l}-2.4708 \\
(0.4884) \\
(0.6194)\end{array}$ & 1.66 & .32 & 66 & $\begin{array}{r}10.69 \star \star \star \star \\
7.73 \star \star \star\end{array}$ \\
\hline $\begin{array}{l}\text { Buyer Bond } \\
\text { Index }\end{array}$ & $\begin{array}{l}1969-1986 \\
\text { quarterly }\end{array}$ & $6 \mathrm{Mns}$ & $\begin{array}{l}-0.3948 \\
(0.0764) \\
(0.0847)\end{array}$ & $\begin{array}{l}-5.165 \star \star \star \\
-4.661 \star \star \star\end{array}$ & $\begin{array}{c}0.2740 \\
(0.1412) \\
(0.1063)\end{array}$ & 1.24 & .31 & 66 & $\begin{array}{l}9.34 \star \star \star \\
9.61 \star \star \star\end{array}$ \\
\hline$\frac{30 \text { Year }}{\text { Mortgages }}$ & $\begin{array}{l}1969-1986 \\
\text { quarterly }\end{array}$ & $6 \mathrm{Mns}$ & $\begin{array}{l}-0.3886 \\
(0.0979) \\
(0.0918)\end{array}$ & $\begin{array}{l}-3.969 \star \star \star \star \\
-4.235 \star \star \star\end{array}$ & $\begin{array}{c}0.6268 \\
(0.1696) \\
(0.0795)\end{array}$ & 1.38 & .27 & 66 & $\begin{array}{r}8.87 \star \star \star \\
33.66 \star \star \star\end{array}$ \\
\hline
\end{tabular}

Notes: Standard errors (in parentheses) are computed using GM under the assumption of homoskedasticity and also allowing for conditional heteroskedasticity, respectively. $\star, \star \star, \star \star \star$ represent significance at the 10,5 and 1 percent levels, respectively. 
Thests $6 \mathrm{~b}$

Tests of Rational sepectations in The

Ten structures of various countries

ous Regressions of

$i_{t+j}^{k-j}-i_{t+j}^{k-j} e=\alpha_{4}+\beta_{4}\left(f_{t}^{i, k-j}-i_{t}\right)+\varepsilon_{t+j}$

\begin{tabular}{|c|c|c|c|c|c|c|c|c|}
\hline $\begin{array}{l}\text { Country } \\
\text { Instrument } \\
(k-j)\end{array}$ & $\begin{array}{l}\text { Data set } \\
\text { Dates }\end{array}$ & $\begin{array}{l}\text { Forecast } \\
\text { Forison } \\
(j)\end{array}$ & $B_{4}$ & $t: B_{4}=0$ & Den & $\overrightarrow{\mathbf{R}}$ & DF & $\begin{array}{c}\text { F Test } \\
a_{4}=0 \\
B_{4}=1\end{array}$ \\
\hline$\frac{\text { US }}{3 \text { Month Euro S }}$ & $\begin{array}{c}\text { MUS } \\
1 / 83-10 / 84 \\
\text { b1weekly }\end{array}$ & 3 Mns & $\begin{array}{l}-1.2458 \\
(0.8516) \\
(0.3282)\end{array}$ & $\begin{array}{l}-1.463 \\
-3.796 \star \star \star\end{array}$ & 0.16 & .07 & 45 & $\begin{array}{l}1.10 \\
7.29 \star \star \star\end{array}$ \\
\hline $\begin{array}{l}\text { West Germany } \\
3 \text { Month Buro Dm }\end{array}$ & $\begin{array}{c}\text { MIS } \\
1 / 83-10 / 84 \\
\text { biweekly }\end{array}$ & $3 \mathrm{Mns}$ & $\begin{array}{c}0.1816 \\
(0.2727) \\
(0.2455)\end{array}$ & $\begin{array}{l}0.666 \\
0.740\end{array}$ & 0.89 & .00 & 45 & $\begin{array}{l}0.77 \\
0.75\end{array}$ \\
\hline $\begin{array}{l}\text { England } \\
3 \text { Month Euro Pound }\end{array}$ & $\begin{array}{c}\text { MHS } \\
1 / 83-10 / 84 \\
\text { biweekly }\end{array}$ & $3 \mathrm{Mns}$ & $\begin{array}{c}1.3550 \\
(0.4273) \\
(0.5955)\end{array}$ & $\begin{array}{l}3.171 \star \star \star \\
2.225 \star \star\end{array}$ & 0.86 & .24 & 45 & $\begin{array}{r}5.22 \star \star \star \\
11.72 \star \star \star\end{array}$ \\
\hline $\begin{array}{l}\text { Japan } \\
3 \text { Month Buro Yen }\end{array}$ & $\begin{array}{c}\text { MHS } \\
\begin{array}{c}1 / 83-10 / 84 \\
\text { biweekly }\end{array}\end{array}$ & 3 Mins & $\begin{array}{c}0.1247 \\
(0.2641) \\
(0.1629)\end{array}$ & $\begin{array}{l}0.472 \\
0.743\end{array}$ & 0.74 & .00 & 45 & $\begin{array}{l}3.16^{\star} \\
3.94^{\star \star}\end{array}$ \\
\hline $\begin{array}{l}\text { Australia } \\
10 \text { Year Treasury } \\
\text { Bonds }\end{array}$ & $\begin{array}{l}\text { MMS } \\
2 / 85-2 / 87 \\
\text { weekly }\end{array}$ & $1 \mathrm{Mn}$ & $\begin{array}{l}0.3260 \\
(0.0691) \\
(0.0891)\end{array}$ & $\begin{array}{l}4.719 \star \star \star \star \\
3.658^{\star \star \star \star}\end{array}$ & 0.93 & .30 & 71 & $\begin{array}{r}11.99 \star \star \star \\
8.17 \star \star \star\end{array}$ \\
\hline
\end{tabular}

Notes: Standard errors (in parentheses) are computed using GMM under the assumption of homoskedasticity and also allowing for conditional heteroskedasticity, respectively.

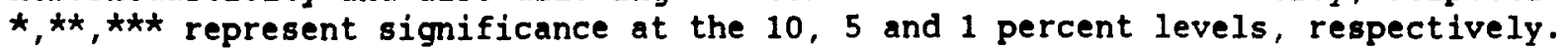


component: in the slope of the Term structure

Nean of:

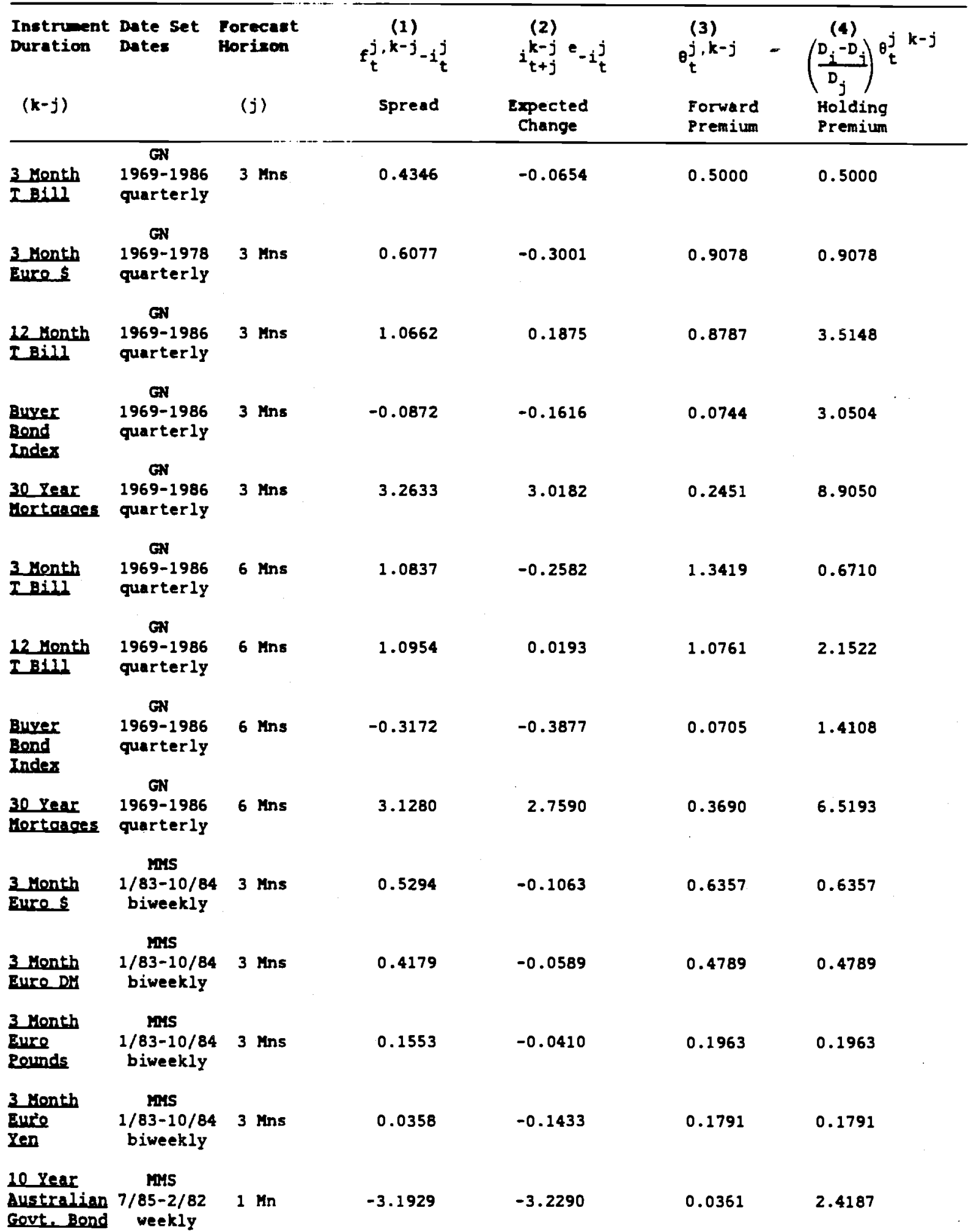




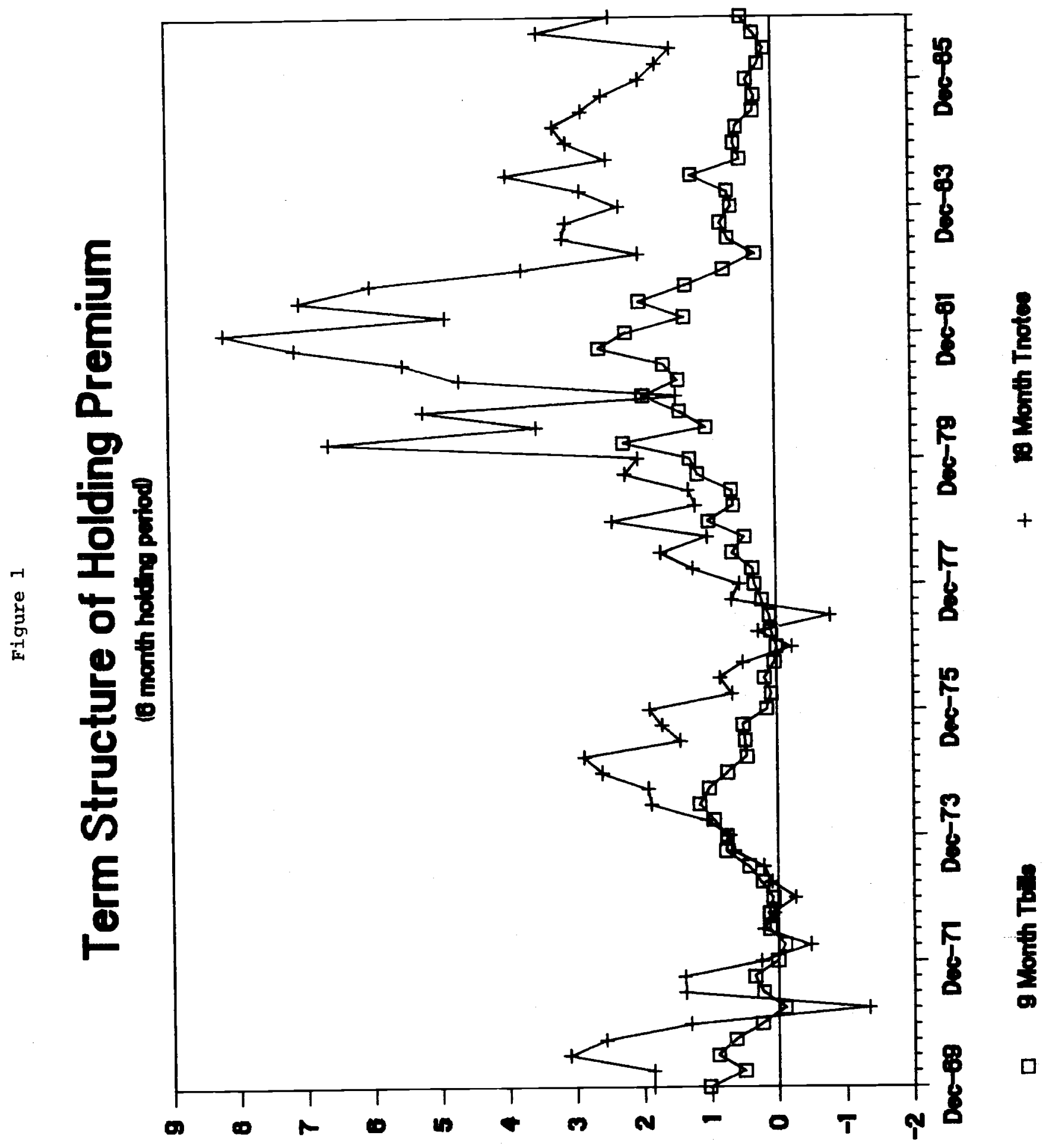

unar and mosed 


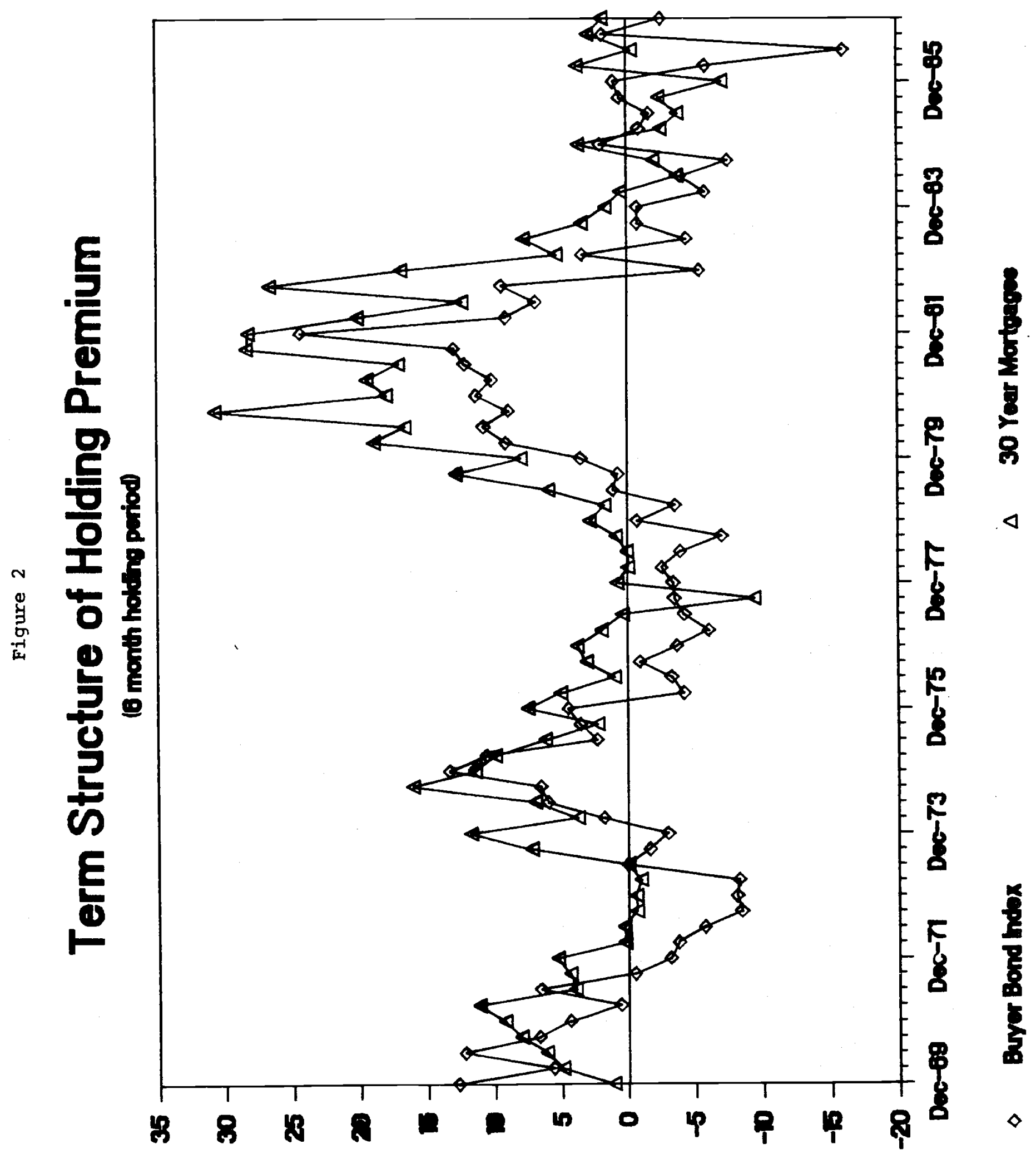




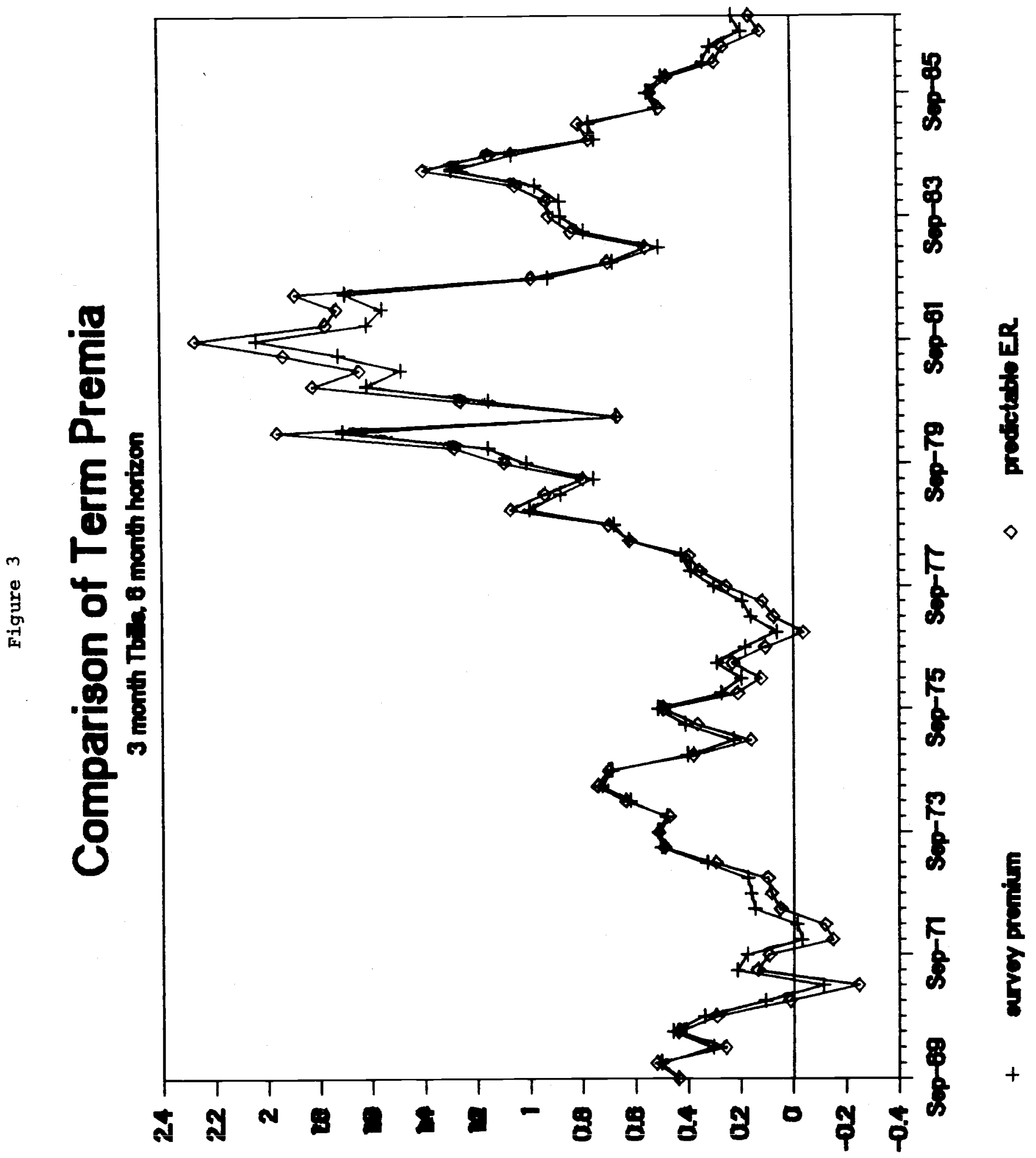




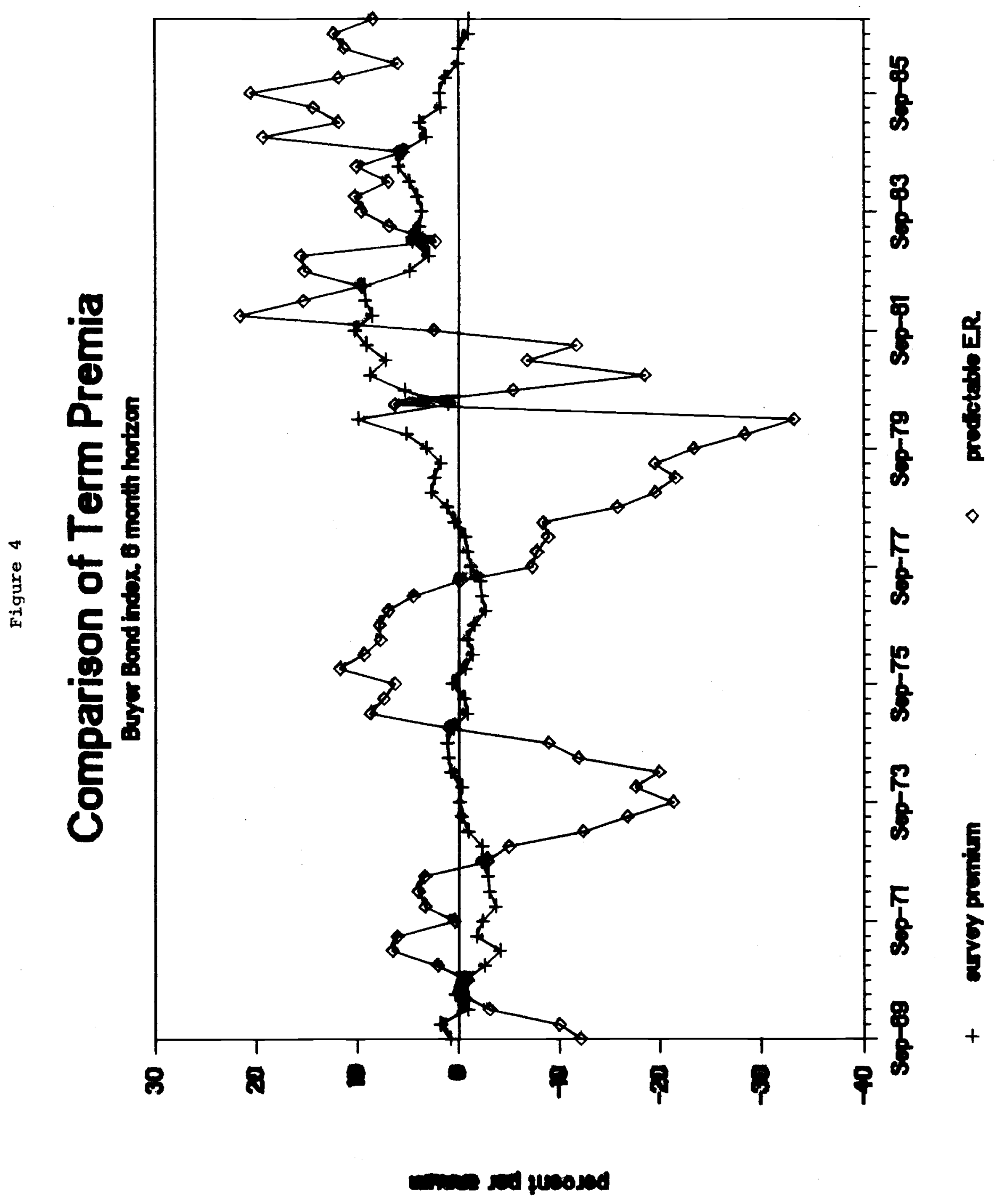


TALS 8

Pariation in Bstiante:

of the Tern Preniu

Variance of $z$

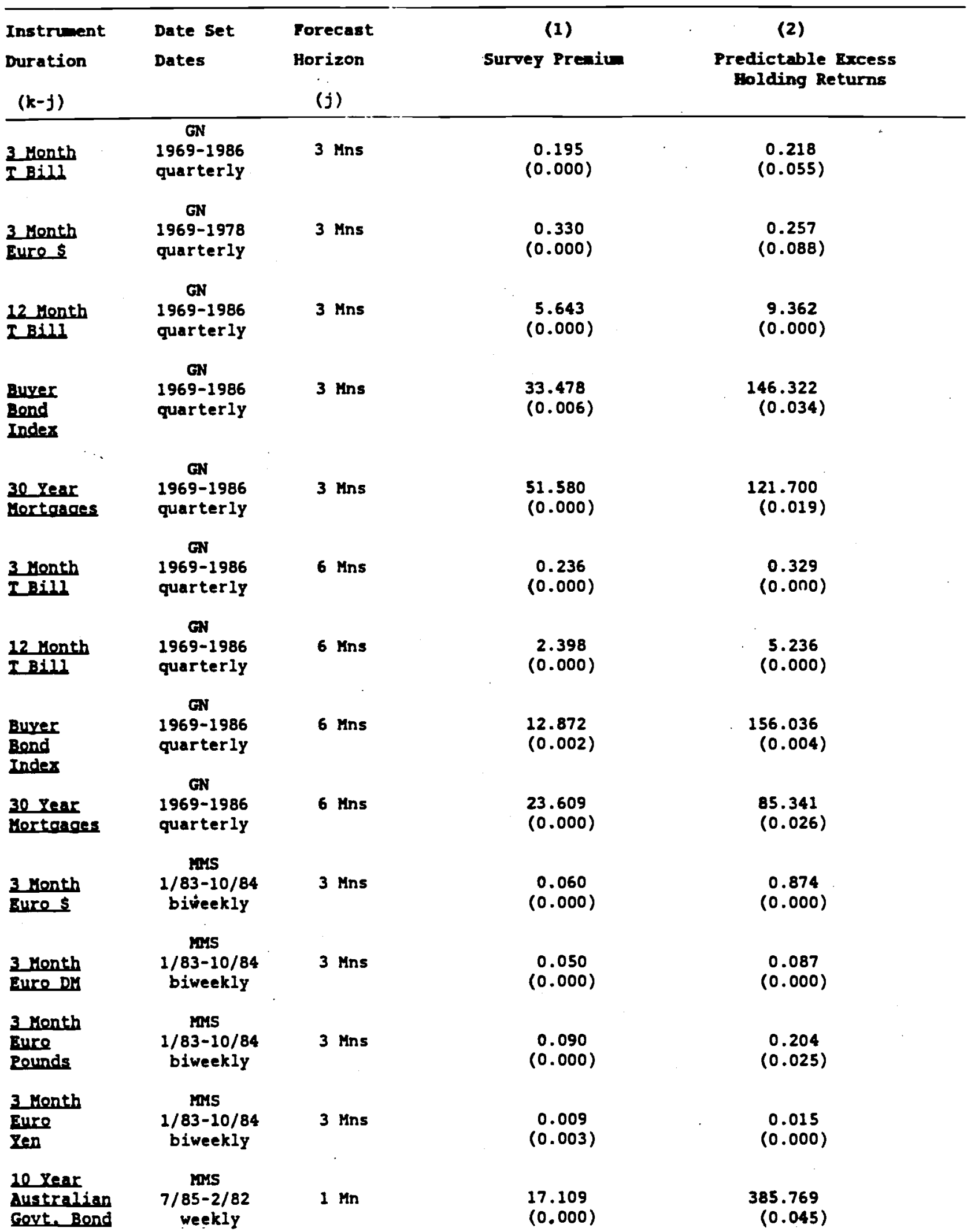

Notes: Figures above are the estimated variances obtained by projecting the survey term premium and realized excess returns, respectively, onto a constant and the appropriate long and short rates. Estimates are annualized variances, expressed in percent. In parenthesis are the probability values from joint $F$-tests that the variances are zero. 